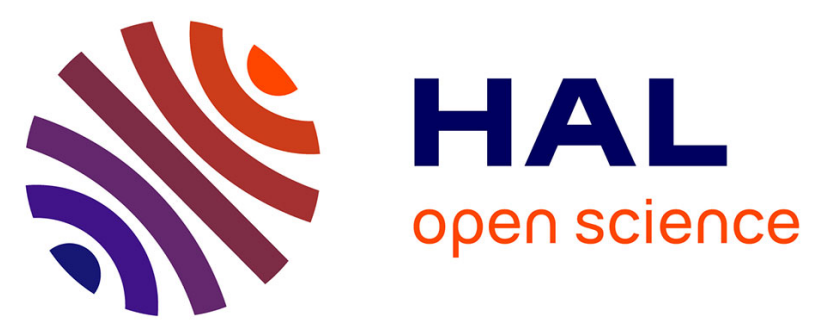

\title{
A New Series of Succinimido-ferrociphenols and Related Heterocyclic Species Induce Strong Antiproliferative Effects, Especially against Ovarian Cancer Cells Resistant to Cisplatin
}

Pascal Pigeon, Yong Wang, Siden Top, Feten Najlaoui, Maria Concepcion Garcia Alvarez, Michael James Mcglinchey, Gérard Jaouen

\section{To cite this version:}

Pascal Pigeon, Yong Wang, Siden Top, Feten Najlaoui, Maria Concepcion Garcia Alvarez, et al.. A New Series of Succinimido-ferrociphenols and Related Heterocyclic Species Induce Strong Antiproliferative Effects, Especially against Ovarian Cancer Cells Resistant to Cisplatin. Journal of Medicinal Chemistry, 2017, 60 (20), pp.8358-8368. 10.1021/acs.jmedchem.7b00743 . hal-01611795

\section{HAL Id: hal-01611795 \\ https://hal.sorbonne-universite.fr/hal-01611795}

Submitted on 6 Oct 2017

HAL is a multi-disciplinary open access archive for the deposit and dissemination of scientific research documents, whether they are published or not. The documents may come from teaching and research institutions in France or abroad, or from public or private research centers.
L'archive ouverte pluridisciplinaire HAL, est destinée au dépôt et à la diffusion de documents scientifiques de niveau recherche, publiés ou non, émanant des établissements d'enseignement et de recherche français ou étrangers, des laboratoires publics ou privés. 
Subscriber access provided by BUPMC - Bibliothèque Universitaire Pierre et Marie Curie

\section{Article}

\section{A new series of succinimido-ferrociphenols and related heterocyclic species induce strong antiproliferative effects, especially against ovarian cancer cells resistant to cisplatin}

Pascal Pigeon, Yong Wang, Siden Top, Feten Najlaoui, Maria Concepcion

Garcia Alvarez, Jérôme Bignon, Michael James McGlinchey, and Gerard Jaouen

J. Med. Chem., Just Accepted Manuscript • DOI: 10.1021/acs.jmedchem.7b00743 • Publication Date (Web): 12 Sep 2017

Downloaded from http://pubs.acs.org on September 13, 2017

\section{Just Accepted}

"Just Accepted" manuscripts have been peer-reviewed and accepted for publication. They are posted online prior to technical editing, formatting for publication and author proofing. The American Chemical Society provides "Just Accepted" as a free service to the research community to expedite the dissemination of scientific material as soon as possible after acceptance. "Just Accepted" manuscripts appear in full in PDF format accompanied by an HTML abstract. "Just Accepted" manuscripts have been fully peer reviewed, but should not be considered the official version of record. They are accessible to all readers and citable by the Digital Object Identifier (DOI®). "Just Accepted" is an optional service offered to authors. Therefore, the "Just Accepted" Web site may not include all articles that will be published in the journal. After a manuscript is technically edited and formatted, it will be removed from the "Just Accepted" Web site and published as an ASAP article. Note that technical editing may introduce minor changes to the manuscript text and/or graphics which could affect content, and all legal disclaimers and ethical guidelines that apply to the journal pertain. ACS cannot be held responsible for errors or consequences arising from the use of information contained in these "Just Accepted" manuscripts. 


\section{A new series of succinimido-ferrociphenols and related heterocyclic species induce strong antiproliferative effects, especially against ovarian cancer cells resistant to cisplatin}

Pascal Pigeon, ${ }^{1,2, \dagger} *$ Yong Wang,,${ }^{1,2 \dagger}$ Siden Top, ${ }^{2}$ Feten Najlaoui, ${ }^{2}$ Maria Concepcion Garcia Alvarez, ${ }^{3}$ Jérôme Bignon, ${ }^{3}$ Michael J. McGlinchey, ${ }^{4}$ and Gérard Jaouen. ${ }^{1,2, *}$

${ }^{1}$ PSL, Chimie ParisTech, 11 rue Pierre et Marie Curie, F-75005 Paris, France

${ }^{2}$ Sorbonne Universités, UPMC Univ Paris 6, UMR 8232 CNRS, IPCM, place Jussieu, F-75005

Paris, France

${ }^{3}$ Centre de Recherche de Gif, Institut de Chimie des Substances Naturelles, UPR $2301 \mathrm{du}$ CNRS, Université Paris-Saclay, 1 Avenue de la Terrasse, 91198, Gif-sur-Yvette Cedex, France

${ }^{4}$ UCD School of Chemistry and Chemical Biology, University College Dublin, Belfield, Dublin 4, Ireland

${ }^{\dagger}$ These authors equally contributed to this work.

*To whom correspondence should be addressed. Gérard Jaouen, gerard.jaouen@upmc.fr; Pascal Pigeon, pascal.pigeon@,chimie-paristech.fr 


\begin{abstract}
Ferrociphenols are known to display anticancer properties by original mechanisms dependent on redox properties and generation of active metabolites such as quinone methides. Recent studies have highlighted the positive impact of oxidative stress on chemosensitivity and prognosis of ovarian cancer patients. Ovarian adenocarcinomas are shown to be an excellent model for defining the impact of selected ferrociphenols as new therapeutic drugs for such cancers. This work describes the syntheses and preliminary mechanistic research of unprecedented multitargeting heterocyclic ferrociphenols bearing either a succinimidyl or phthalimidyl group that show exceptional antiproliferative behavior against epithelial ovarian cancer cells resistant to cisplatin. Owing to the failure of the present pharmaceutical options, such as carboplatin a metallodrug based on Pt coordination chemistry, these species may help to overcome the problem of lethal resistance. Currently, ferrociphenolic entities generally operate via apoptotic and senescence pathways. We present here our first results in this new cyclic-imide series.
\end{abstract}

Keywords. antitumor agents, bioorganometallics, ferrocene, imides, quinones 


\section{Introduction}

Burgeoning numbers of organometallic complexes bearing ferrocenyl moieties are currently appearing in the literature, with the intended goal of medicinal applicability. ${ }^{1-12}$ In this context, our long term project aims to study selected ferrociphenols ${ }^{13-15}$ chosen for their innovative behavior against intractable cancers. We here focus on epithelial ovarian cancer (EOC), a disease that remains a serious therapeutic roadblock with no significant advances because of the failure of the present pharmaceutical options. EOC remains one of the deadliest gynaecological malignancies; standard protocol consists of surgery and chemotherapy. Despite an initial response to therapy, many patients become resistant to treatment and ultimately die. However, although there is increasing evidence that precision therapy targeted to molecular cancer drivers can improve clinical outcomes, high-grade EOC patients are currently treated without consideration of molecular phenotype. Molecular features of high-grade serous EOC could be helpful in fulfilling this need. ${ }^{16-17}$ There is compelling evidence that redox regulation plays an essential role in malignancies. Recent studies by Mechta-Grigoriou et al. have highlighted the positive impact of oxidative stress on chemosensitivity and ovarian cancer prognosis. ${ }^{16,18}$ Interestingly, the redox properties of new ferrociphenols could fit very well with these findings.

The original antiproliferative behavior of ferrociphenols lies in the redox properties of the [ferrocenyl-ene-phenol] motif (Scheme 1) producing ROS (Reactive Oxygen Species) ${ }^{19}$ on cancer cells, and subsequent generation of selective electrophiles such as QMs (Quinone Methides). ${ }^{20-23}$ These active metabolites are able to react with specific receptor proteins or enzymes such as thioredoxin reductases, ${ }^{23}$ or AP1, IL-6, IL-8 signaling pathways, ${ }^{24}$ and induce apoptosis and/or senescence. ${ }^{14,23-25}$ These multitargeting species can inhibit or slow down resistance problems on cancer cells, and in addition are not at all, or poorly, active on healthy 
cells. ${ }^{14}$ Given (i) the crucial role of oxidative stress in the biology of some epithelial ovarian cancers, ${ }^{16}$ (ii) the resistance of ovarian cancers to Paclitaxel and Carboplatin regimens, and (iii) the medicinal need for new therapeutics in this type of cancer, we have selected ovarian adenocarcinomas as a good model on which to perform in vitro mechanistic/biological studies with selected new ferrociphenols.

Ideally, an improved generation of products is required to address new mechanisms of action. These compounds should involve unequivocally characterized primary metabolites, and must also exhibit lower $\mathrm{IC}_{50}$ values than those of the drug candidates known so far. In all the early modifications of 1 the ethyl entity was left untouched and, when chains were modified, this occurred mostly on the phenol side. ${ }^{13}$ It is only recently that we have begun to consider modification of the alkyl chain by attaching an $\mathrm{OH}$ group to the end, and we have obtained particularly low $\mathrm{IC}_{50}$ values $\left(\mathrm{IC}_{50}=0.11 \mu \mathrm{M}\right)$ with 2a on triple negative breast cancer cell lines (MDA-MB-231), ${ }^{26}$ moreover, the bioactivity of their metabolites, all of which have been identified, was also evaluated. ${ }^{27-28}$ Meanwhile a number of recent research projects have focused on biologically-oriented ferrocene compounds substituted by heterocyclic skeletons, including for example nucleobases, sugars or flavonoids. ${ }^{29-41}$ In this context, the novel series shown below seems particularly appealing whereby a heterocyclic group such as succinimidyl or phthalimidyl, as in $\mathbf{3}$ or $\mathbf{4}$, respectively, has been incorporated into the molecule. We note that in bioorganometallic chemistry, examples of compounds that have significantly low $\mathrm{IC}_{50}$ values on EOC cells resistant to cisplatin are practically nonexistent, except for rare complexes of ruthenium or osmium, having structures different from the ferrociphenols, and which appear promising. ${ }^{42-43}$ Amongst our more recently synthesized and patented compounds, ${ }^{15}$ these 


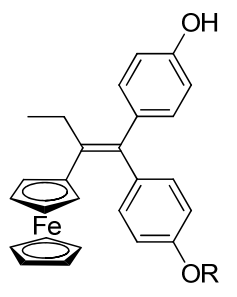

1a: $\mathrm{R}=\mathrm{H}$ 1b: $\mathrm{R}=\left(\mathrm{CH}_{2}\right)_{3} \mathrm{~N}\left(\mathrm{CH}_{3}\right)_{2}$

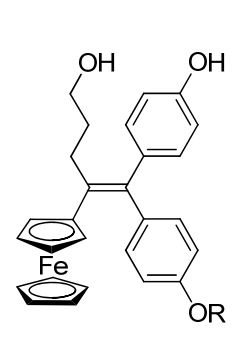

2a: $\mathrm{R}=\mathrm{H}$ 2b: $\mathrm{R}=\left(\mathrm{CH}_{2}\right)_{3} \mathrm{~N}\left(\mathrm{CH}_{3}\right)_{2}$

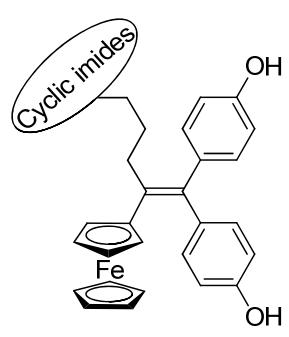

Cyclic imides:

3: succinimide 4: phthalimide

Scheme 1. Incorporation into the ferrociphenol skeleton, $\mathbf{1}$, of a hydroxyl group, in $\mathbf{2}$, or a cyclicimide, in $\mathbf{3}$ and $\mathbf{4}$.

We here report the syntheses, characterization and first biological results of a series of novel complexes obtained by incorporation of imide-type heterocycles at the terminus of the alkyl chain, as in 3 and 4 (Scheme 1). These molecules form a new group of chemical products, but their chief interest lies in the encouraging early biological results obtained for some of these products, in the form of strong antiproliferative effects on ovarian cancer cell lines. They are the founding members of a particularly innovative and effective family of heterocyclic ferrociphenols.

\section{Results and Discussion}

\section{Syntheses}

Preparation of the chlorinated ferrocene ketones with a three or four methylene chain, 5a and 5b, by Friedel-Crafts acylation of ferrocene, followed by McMurry coupling, furnished the heavily substituted alkenes $\mathbf{6 a}^{44}$ and $\mathbf{6 b}$ in yields of 68 and $60 \%$, respectively. Subsequent reaction with an imide (succinimide, glutarimide or phthalimide) in a basic medium (potassium carbonate in DMF) at $80{ }^{\circ} \mathrm{C}$ gave the novel mono-heterocyclic ferrociphenols $\mathbf{3}, \mathbf{7}$ and $\mathbf{8}$, in yields 
of 54, 22 and 58\%, respectively, and the known phthalimide, 4, in $83 \%$ yield. ${ }^{44}$ The new complexes were characterized spectroscopically and, in the case of the succinimido derivative, 3 , by X-ray crystallography (Figure 1).
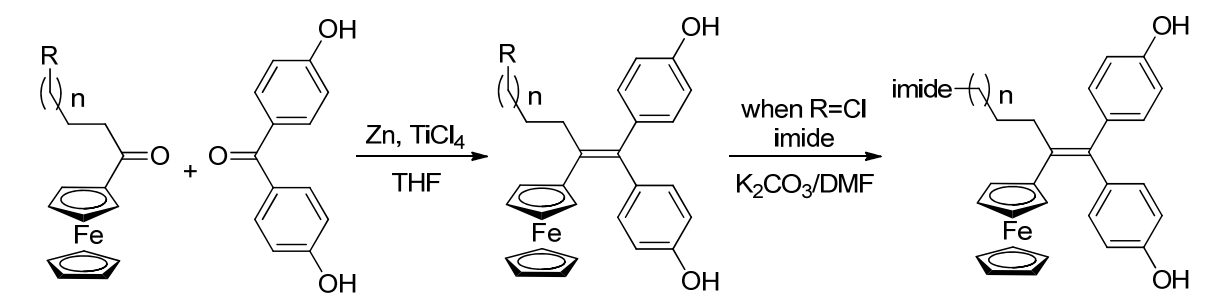

$5 \mathbf{a}: \mathrm{n}=1, \mathrm{R}=\mathrm{Cl}$
$\mathbf{5 b}: \mathrm{n}=2, \mathrm{R}=\mathrm{Cl}$

5c: $n=1, R=H$

6a: $n=1, R=C l$

6b: $n=2, R=C l$

6c: $n=1, R=H$

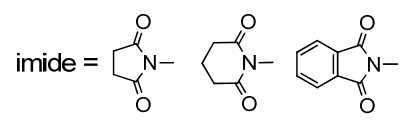

3: $n=1 \quad$ 7: $n=1 \quad 4: n=1$

8: $n=2$

Scheme 2. Synthesis of the imides $3,4,7,8$, and of the non-substituted propyl derivative $\mathbf{6 c}$.

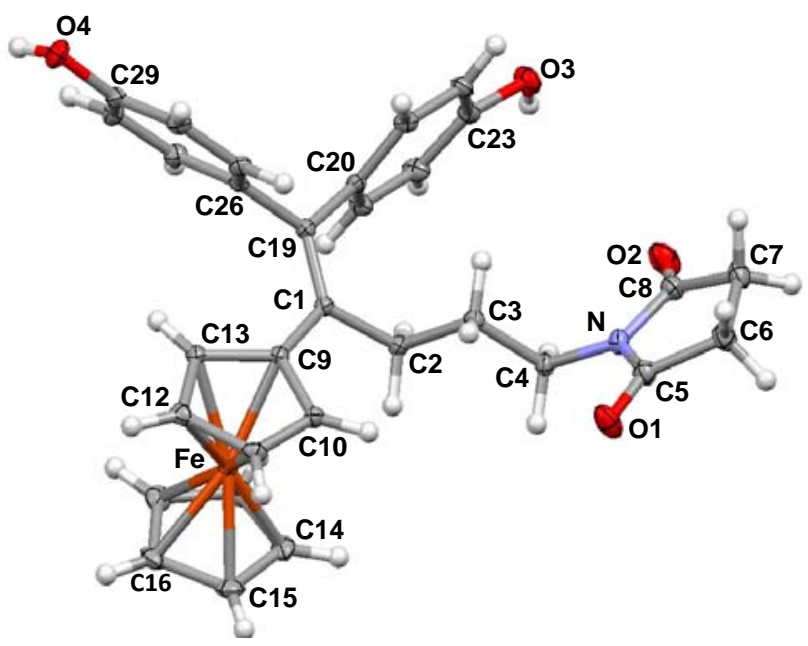

Figure 1. X-ray structure of $N$-[4-ferrocenyl-5,5-bis-(4-hydroxyphenyl)-pent-4-enyl]succinimide, 3 (thermal ellipsoids are shown at 50\%).

To better assess the effect of attaching an imide at the end of the chain, we compared the cytotoxicity of each of these species with that of the reference compound 1a, which has no such attachment. Moreover, for even better comparison, we also specifically synthesized compound $\mathbf{6 c}$, 
which has a propyl group, with the same number of carbon atoms in the chain as compounds $\mathbf{3}, \mathbf{4}$ and 7. The synthetic route is the same as for the chlorinated compounds, starting from the commercially-available ferrocenyl propyl ketone 5c.

In order to investigate possible mechanisms for the antiproliferative action of our cyclic-imidyl ferrociphenols, we based our studies on two types of potential metabolites. We focused initially on the "ferrociphenol" motif $\left(\mathrm{Fc}-\mathrm{C}=\mathrm{C}-\mathrm{C}_{6} \mathrm{H}_{4}-\mathrm{OH}\right)$, known to lead to oxidation with formation of a QM in a biological medium. ${ }^{27-28}$ Subsequently, we looked at the imide component, which is capable of producing specific ring-opened metabolites.

One of the likely mechanisms that we have previously identified to explain the cytotoxic effect of ferrocenyl phenols on various cancer cells is based on their in situ transformation to electrophilic QMs, which are potentially cytotoxic species. This process is mediated by the ferrocenyl group and allows QM formation to occur under comparatively mild (i.e. biologically relevant) oxidation conditions. We propose that the strong antiproliferative activity of $\mathbf{3}$ as a precursor compound is also related to QM formation inside cells. Thus, we first explored the chemical oxidation of 3 (by $\mathrm{Ag}_{2} \mathrm{O}$ ) to produce the vinyl 3-QM (Scheme 3) that was fully characterized by ${ }^{1} \mathrm{H}$ and ${ }^{13} \mathrm{C}$ NMR spectroscopy and mass spectrometry. The ${ }^{1} \mathrm{H}$ NMR spectrum revealed an approximate $3: 1$ ratio of $E / Z$ isomers, which can be explained by the steric issue we proposed recently. ${ }^{28}$

Molecule 3-QM showed a far better stability profile (half-life in acetone of about 10 days!) than the corresponding QM of 1a which was unstable, and even started to decompose before oxidation was complete. ${ }^{20}$ It was also superior to the tetrahydrofuran-substituted $\mathbf{2 a - Q M}\left(\mathrm{t}^{1} / 2\right.$ in acetone $\sim 30 \mathrm{~h}$ ), resulting from the oxidation of $2 \mathbf{a}^{26}$ These preliminary results have been 
obtained by oxidation using rat liver microsomes (containing cytochrome P450, to be published). Since the two-electron chemical oxidation data of 3 with $\mathrm{Ag}_{2} \mathrm{O}$ confirmed that the vinyl derivative 3-QM is main species formed, the probable formation of 3-QM inside cells may be anticipated, as with other ferrociphenols. ${ }^{14}$

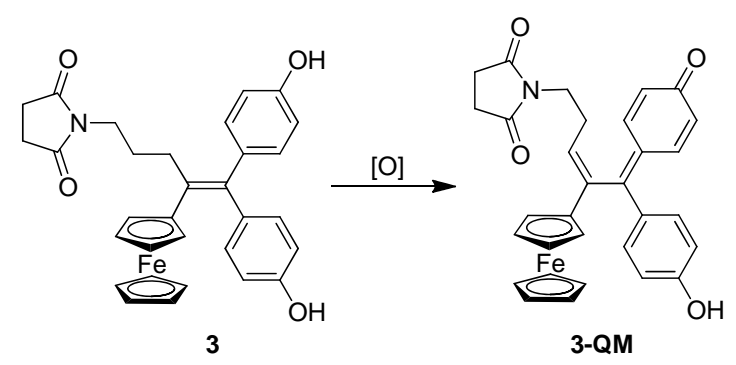

Scheme 3. Formation of 3-QM by chemical or metabolic oxidation.

The redox behavior of ferrociphenols mediated by the ferrocenyl can also be followed by electrochemistry. Cyclic voltammetric experiments (Figure 2) show that, in the absence of imidazole, compounds 3 and 4 exhibit a reversible monoelectronic oxidation process at $0.51 \mathrm{~V}$ and $0.49 \mathrm{~V}$, respectively, ascribed to ferrocenyl oxidation, as already established for other ferrociphenols. ${ }^{21}$ Upon addition of 20 equivalents of base, they showed very similar electrochemical behavior with that we reported before, ${ }^{21}$ involving a base-promoted intramolecular electron transfer between the phenol and the ferrocenium cation to give a quinone methide. 

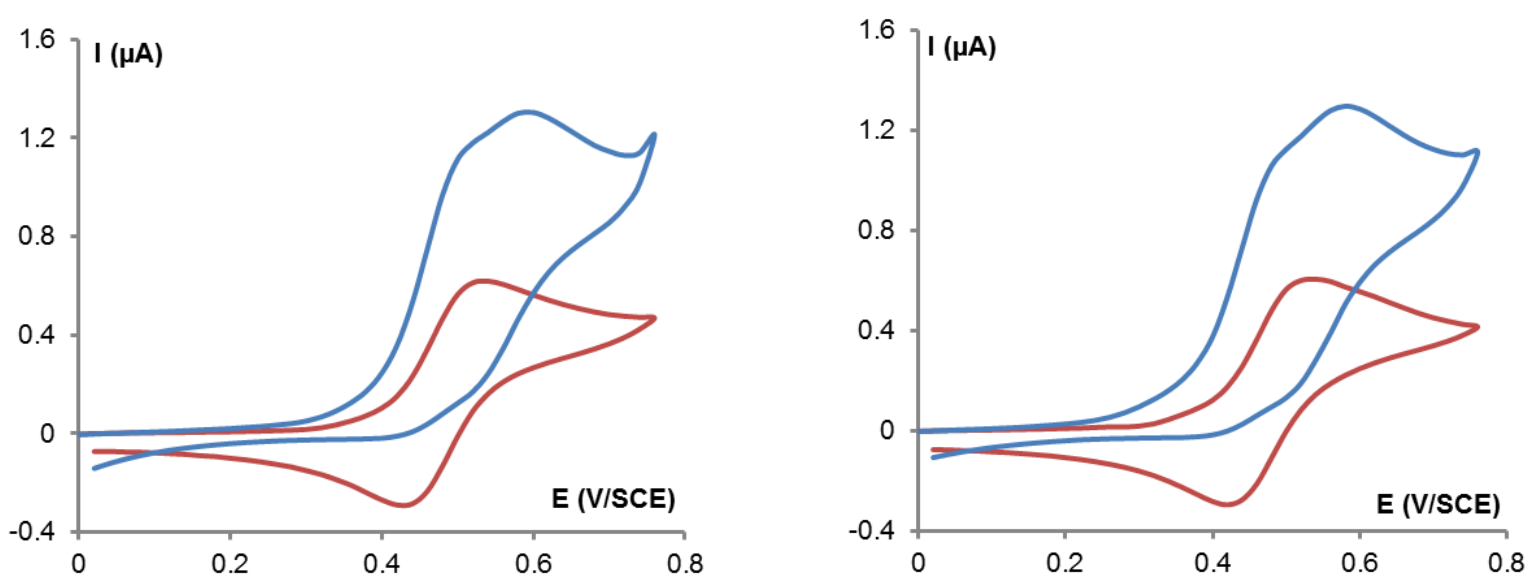

Figure 2. Cyclic voltammograms of 3 (approximately $1 \mathrm{mM}$, scan rate $200 \mathrm{mV} / \mathrm{s}$, left) and 4 (approximately $1 \mathrm{mM}$, scan rate $200 \mathrm{mV} / \mathrm{s}$, right) in the absence of base (red curve) and in the presence of $20 \mathrm{mM}$ imidazole (blue curve).

Another possible mechanism involves opening the imide rings. It is known that thalidomide, a compound of the imide family, is at least partly metabolized by ring-opening its two imide functions (phthalimide and glutarimide) ${ }^{45}$ We decided to examine the possibility that this opening of the imide ring could be occurring and, if so, would it explain the unusual biological activity (see below) of our compounds, particularly $\mathbf{3}$ and $\mathbf{4}$. In order to test their activity $\left(\mathrm{IC}_{50}\right)$, and to compare it with that of the parent products, we synthesized these presumed metabolites by basic hydrolysis, thus opening the imido rings. The action of sodium hydroxide on these compounds dissolved in a water/ethanol mixture at room temperature gave the ring-opened products $\mathbf{9}$ and $\mathbf{1 0}$ in yields of 98 and 78\%, respectively. These products were characterized spectroscopically and, in the case of $\mathbf{9}$, by X-ray crystallography; its structure is shown as Figure 3. 

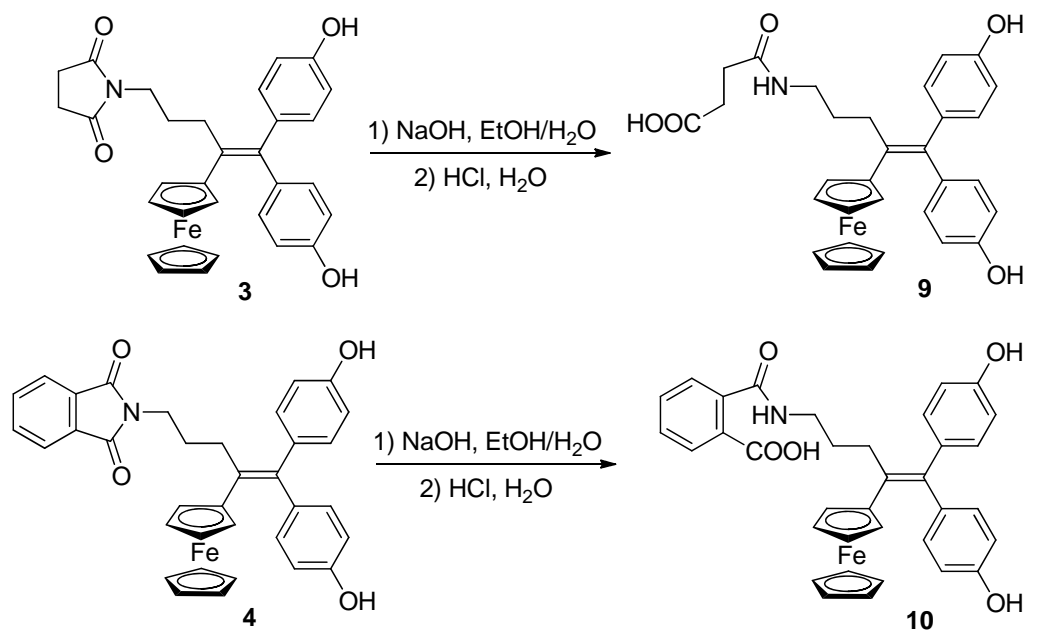

Scheme 4. Formation of the presumed ring-opened metabolites, 9 and 10, from the succinimidyland phthalimidyl-ferrociphenols 3 and $\mathbf{4}$, respectively.

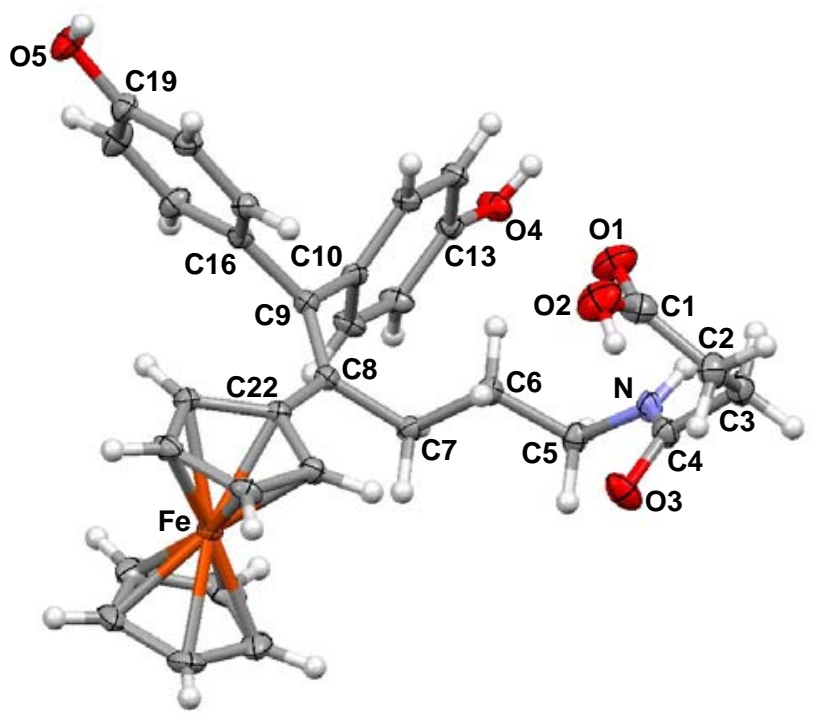

Figure 3. Molecular structure of 5-(2'-carboxypropamido)-2-ferrocenyl-1,1-bis-(4-hydroxyphenyl)-pent-1-ene, 9 (thermal ellipsoids are shown at 50\%). 


\section{Biological studies}

In this laboratory, preliminary cytotoxicity tests on MDA-MB-231 cancer cells have been routinely used to evaluate the anticancer activity of our molecules. Historically, our molecules were seen as derivatives of tamoxifen and thus were initially compared to its behavior against hormone-independent (MDA-MB-231) and hormone-dependent (MCF-7) breast cancer cell lines. However, over time the structure of these molecules has departed more and more from that of tamoxifen, with the result that limiting them to only breast cancers is no longer justified. Thus, we have chosen to test the activity of our new heterocyclic ferrociphenols on three ovarian epithelial cancer cell lines, one of which is resistant to cisplatin (A2780, A2780-Cis and SK-OV3). As shown in Table 1, we also compared the new species to molecules from our library of ferrociphenols known for their strong activity: the first ferrociphenol that we synthesized, 1a, its cyclic version [3] ferrocenophane, 11, and the hydroxypropyl product 2a. Finally, 6c was added to the list to keep the same number of carbon atoms in the chain, and so better assess the effect of the attachment of a hydroxyl or cyclic-imidyl group to the end of the propyl chain. We can already see that lengthening the carbon chain from three to four methylene units diminishes the anticancer activity, and this holds true for all the lines tested.

Since increasing the length of the non-polar carbon chain on the north-west side of the molecule, which affects both steric hindrance and lipophilicity, seems to have a negative influence, we chose to study the effect of attaching a polar group onto the propyl chain. Thus, the hydroxyl group, which is small, makes it possible to improve the activity of 2a on all the lines tested compared to $\mathbf{6 c}$, and even compared to 1a. This shows that the positive effect of the hydroxyl overcomes the negative effect linked to the steric hindrance such that this latter parameter seems less important than the presence of this polar and protic group. 
Table 1. Activity of products $\left(\mathrm{IC}_{50} \mu \mathrm{M}\right)$ on ovarian cancer (A2780, A2780-Cis and SK-OV3) and $\log \mathrm{Po} / \mathrm{w}$ results for selected ferrocenyl compounds.

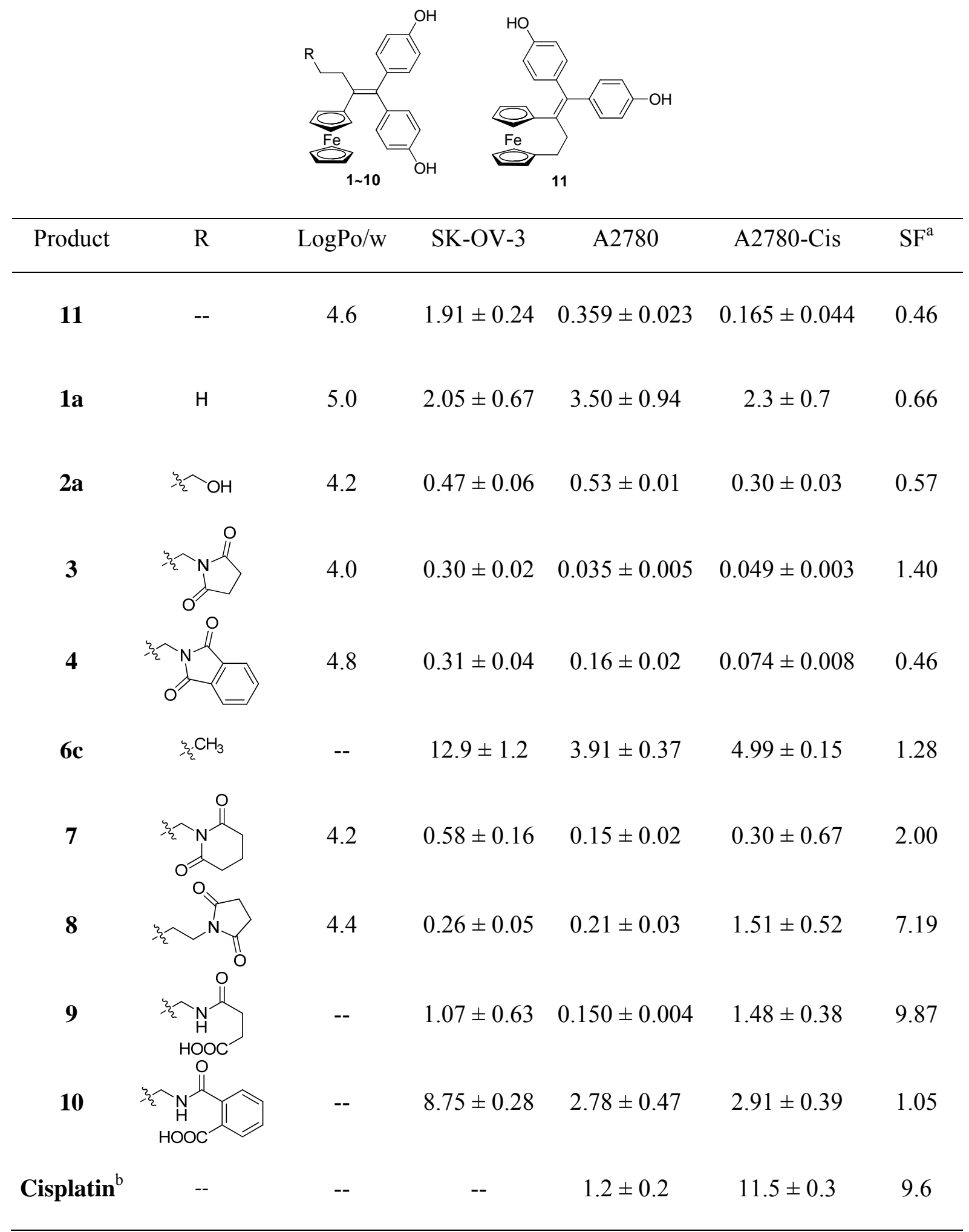


(a) Selectivity Factor (Ratio $\mathrm{IC}_{50}$ A2780-Cis / $\mathrm{IC}_{50}$ A2780); (b) Values taken from ref. 53.

In light of these data, it was decided to test the attachment of a larger polar group, this time aprotic, such as the imide rings. Compounds 3 and $\mathbf{4}$, bearing succinimido or phthalimido substituents, respectively, show a large improvement in antitumoral activity on the three ovarian cancer cell lines with $\mathrm{IC}_{50}$ values below $0.08 \mu \mathrm{M}$ on A2780-Cis, resistant to cisplatin, as well as on the A2780 line for 3. These results on ovarian cancer are systematically better than those of 2a, even though the size of these two imides is substantially greater than that of a single hydroxyl group. The results are also better than those of [3]ferrocenophane, 11. This is an important finding, considering that the cyclic compounds ([3]ferrocenophanes) were previously always thought to be more antiproliferative than non-cyclic compounds, ${ }^{22,}{ }^{46}$ and that none of our noncyclic compounds had ever had an $\mathrm{IC}_{50}$ value below $0.1 \mu \mathrm{M}$ on the lines tested. Evidently, the cyclic imido species are the start of a new paradigm.

To examine what makes these imides so unusual, in particular, the most active of them, $\mathbf{3}$, we made slight structural modifications by increasing the number of carbons through addition of a methylene group. However, enlargement of the succinimide ring to a glutarimide ring, as in $\mathbf{7}$, resulted in loss of activity by a factor of four relative to A2780 and A2780-Cis. Even more strikingly, incorporation of the additional methylene unit to 3 by increasing the chain length from 3 to 4 carbon atoms, as in $\mathbf{8}$, triggers a global loss of activity that is even greater than that for the glutarimide, 7. The best combination therefore appears to be a chain of three methylenes and a planar five-membered imide ring. It should be noted that the phthalimide $\mathbf{4}$, which also possesses these two characteristics, is the closest compound to $\mathbf{3}$ in terms of activity, despite having an additional non-polar benzene ring that increases steric hindrance and lipophilicity. However, 4 is unusual in being twice as active (selectivity factor SF $=0.46$ ) on the cisplatin-resistant line 
A2780-Cis compared to A2780 (comparable to the non-heterocyclic ferrociphenols 1a, 2a and 11, but with much higher activity). Although the succinimido complex, $\mathbf{3}$, is a little more selective in terms of $\mathrm{A} 2780$, its $\mathrm{IC}_{50}$ value on $\mathrm{A} 2780$-Cis is 1.5 times better than that of its phthalimido counterpart, 4.

We next attempted to investigate the possible metabolites of $\mathbf{3}$ and $\mathbf{4}$. It has already been shown that ferrociphenols undergo oxidation to QMs which can influence activity. ${ }^{27-28}$ We now see that molecule 3 follows the same path, and its QM has been isolated (see above). However, these new molecules contain cyclic imides that are known to form metabolites by ring opening, as in thalidomide. ${ }^{45}$ Having independently synthesized compounds $\mathbf{9}$ and $\mathbf{1 0}$, and finding that their $\mathrm{IC}_{50}$ values were not as potent as those of the parent imides, one might suggest that these species are broadly not involved as metabolites, or are metabolites that are not active on these targets. This statement must be tempered, however, by the fact that we have previously shown that QMs and their indenyl ring products are less active than their ferrociphenol precursors, despite admittedly being active metabolites. ${ }^{27}$ We justified this finding by the fact that the metabolite must form in the cell very close to its biological target to avoid any interaction with other molecules in its path as it approaches the target. ${ }^{27}$ The ring-opened molecules $\mathbf{9}$ and $\mathbf{1 0}$ could thus also potentially form inside the cell, but this remains to be determined. Their higher polarity compared to the precursor imide (attributable to their two polar protic functions, the secondary amide, and particularly the carboxylic acid), could also be an issue when they are introduced directly into the culture medium. Indeed, lipophilicity is an important parameter for the entry of molecules into the cell, ${ }^{47}$ and the carboxylic function, which must exist as a carboxylate at the $\mathrm{pH}$ level of the culture medium should play an important role. 
We note that the phthalimide 4 is structurally very close to one of our recently published compounds, $12,{ }^{48}$ the difference being insertion of an oxygen atom between the nitrogen atom of the phthalimide group and the chain. Activity on MDA-MB-231 was $13.31 \mu \mathrm{M}$, compared to $\mathrm{IC}_{50}$ values of $0.15 \mu \mathrm{M}$ for 4 and $0.30 \mu \mathrm{M}$ for 8 (Table 2), less potent by a factor of 89 and 44 respectively, despite the fact that this compound bears a group that is fairly equivalent to that of $\mathbf{4}$ in terms of polarity and size. This demonstrates the highly unusual properties of our imides and in particular of their linkages [imide_chain carbons_-ferrociphenol].

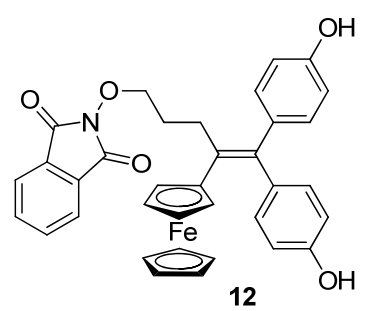

Scheme 5. Compound 12, analogue of 4 and 8.

Encouraged by the exceptional results obtained with our two best products, $\mathbf{3}$ and $\mathbf{4}$, on these three ovarian cancer cell lines, we wished to establish whether they showed an equally potent activity on other cancers (Table 2 ). We thus measured their $\mathrm{IC}_{50}$ values on triple negative breast cancer cell lines (MDA-MB-231), colorectal cancer (HCT-116) and pancreatic cancer (MiaPaCa-2) cell lines, as well as those of two leukemias, one of them resistant to Doxorubicin (K562 and K562R). For comparison, tests were also carried out on our structurally close flagship products, 1a and 2a, as well as 8, 9 and 10. Compound $\mathbf{3}$ is the most active overall, followed by 2a and 4. A decrease in the cytotoxic activity of these compounds on the K562R cell line compared to the K562 line seems to indicate that they may be partial substrates of the Pgp protein overexpressed in this cell line and responsible for its resistance to Doxorubicine. However, with 
selectivity factors $\left(\mathrm{IC}_{50} \mathrm{~K} 562 \mathrm{R} / \mathrm{IC}_{50} \mathrm{~K} 562\right)$ of under 5, while the equivalent value is 745 for Doxorubicine, ${ }^{49}$ 1a, 2a, 4 and 10 seem resistant to this phenomenon, unlike $\mathbf{3}(85)$ and $\mathbf{9}(>357)$.

Table 2. $\mathrm{IC}_{50}(\mu \mathrm{M})$ of certain molecules on other cell lines: triple negative breast cancer (MDAMB-231), colorectal cancer (HCT 116), pancreatic cancer (Mia-PaCa-2), leukemia (K562 and K562R).

\begin{tabular}{|c|c|c|c|c|c|}
\hline Molecule & MDA-MB-231 & HCT116 & Mia-Paca-2 & K562 & K562R \\
\hline $1 \mathbf{a}$ & $0.66 \pm 0.02$ & $4.24 \pm 0.02$ & $11.3 \pm 1.8$ & $3.32 \pm 1.10$ & $2.74 \pm 0.27$ \\
\hline $2 \mathbf{a}$ & $0.11 \pm 0.02$ & $1.21 \pm 0.25$ & $1.23 \pm 0.01$ & $1.99 \pm 0.52$ & $3.11 \pm 1.41$ \\
\hline 3 & $0.035 \pm 0.005$ & $0.140 \pm 0.001$ & $0.13 \pm 0.04$ & $0.048 \pm 0.003$ & $4.1 \pm 0.9$ \\
\hline 4 & $0.145 \pm 0.005$ & $0.33 \pm 0.03$ & $10.4 \pm 1.5$ & $0.50 \pm 0.14$ & $2.48 \pm 0.59$ \\
\hline 8 & $0.30 \pm 0.08$ & $0.160 \pm 0.001$ & $15.94 \pm 2.17$ & $2.71 \pm 0.41$ & $2.74 \pm 0.20$ \\
\hline 9 & $7.75 \pm 0.31$ & $0.11 \pm 0.02$ & $0.48 \pm 0.08$ & $0.14 \pm 0.02$ & $>50$ \\
\hline 10 & $1.01 \pm 0.35$ & $4.78 \pm 0.34$ & $2.75 \pm 0.36$ & $2.81 \pm 0.15$ & $14.0 \pm 3.90$ \\
\hline
\end{tabular}

Five compounds were next tested on human pulmonary fibroblasts (MRC5) in order to evaluate their cytotoxic activity on non-cancerous cells (Table 3). For all the compounds tested, lower cytotoxicity was observed than that seen on A2780 and A2780-Cis cell lines, translating to a ratio greater than 1 . Thus, in order of decreasing $\mathrm{IC}_{50} \mathrm{MRC} 5$ relative to $\mathrm{IC}_{50} \mathrm{~A} 2780$-Cis we see: $\mathbf{2 a}=28.5>\mathbf{4}=27.8>>\mathbf{1 1}=3.8>\mathbf{1 a}=3.2>\mathbf{3}=2.0$. Compound 3 , which is the most active on ovarian cancer cells, does not have the highest ratio. However, this compound is 17 times less toxic on MRC5 than Calicheamicin, for which we recorded an $\mathrm{IC}_{50}$ value of $5.87 \mathrm{nM}$, and 11 
times less than Paclitaxel (9.2 nM), both of which are used as anticancer drugs. On the other hand, compounds $\mathbf{2 a}$ and $\mathbf{4}$ are 30 times less active on healthy cells than on cancer cells, for which they possess a high level of cytotoxicity, and this indicative criterion suggests them as good candidates for drug development.

Table 3. $\mathrm{IC}_{50}$ in $\mu \mathrm{M}$ of MRC5 and the ratios $\mathrm{IC}_{50}$ of MRC5 / $\mathrm{IC}_{50}$ of A2780 or A2780-Cis

\begin{tabular}{cccc}
\hline Product & $\mathrm{IC}_{50}$ & ${\text { Ratio } \mathrm{IC}_{50}}$ & Ratio $\mathrm{IC}_{50}$ \\
& MRC5 & MRC5/A2780 & MRC5/ A2780-Cis \\
\hline $\mathbf{1 1}$ & $0.63 \pm 0.15$ & 1.8 & 3.8 \\
1a & $7.28 \pm 0.39$ & 2.1 & 3.2 \\
2a & $8.54 \pm 0.32$ & 16.1 & 28.5 \\
$\mathbf{3}$ & $0.10 \pm 0.03$ & 2.9 & 2.0 \\
$\mathbf{4}$ & $2.06 \pm 0.97$ & 12.9 & 27.8 \\
& & & \\
\hline
\end{tabular}

\section{Cell cycle analysis and apoptosis}

The effect of compound 3 on the progression of A2780-Cis cells was evaluated in the different phases of the cell cycle. The cancer cells were cultivated in the absence or presence of $\mathbf{3}$ and their distribution in the different phases of the cycle were analysed by flow cytometry after double labeling with propidium iodide and incorporation of BrdU (Figure 4). When A2780-Cis cells were treated for $24 \mathrm{~h}$ with 3 , it can be clearly observed that this compound leads in a dosedependent fashion to an increase in the number of cells in the synthesis phase (phase $\mathrm{S}$ ) of the 
cell cycle. This has already been observed for $\mathbf{1 1}$ and 1a, where a senescence route has been identified. ${ }^{24}$ From $50 \mathrm{nM}$, it can be seen that there are no more cells that have incorporated BrdU (synthetic phase marker), suggesting that a portion of the cells that were sensitive to the action of 3 have been destroyed and that they are no longer quantifiable by flow cytometry. The rest of the cells affected by 3 have a DNA content between $2 n$ and $4 n$ after incorporation of propidium iodide and are found to be localized between the G0-G1 and G2-M phases.
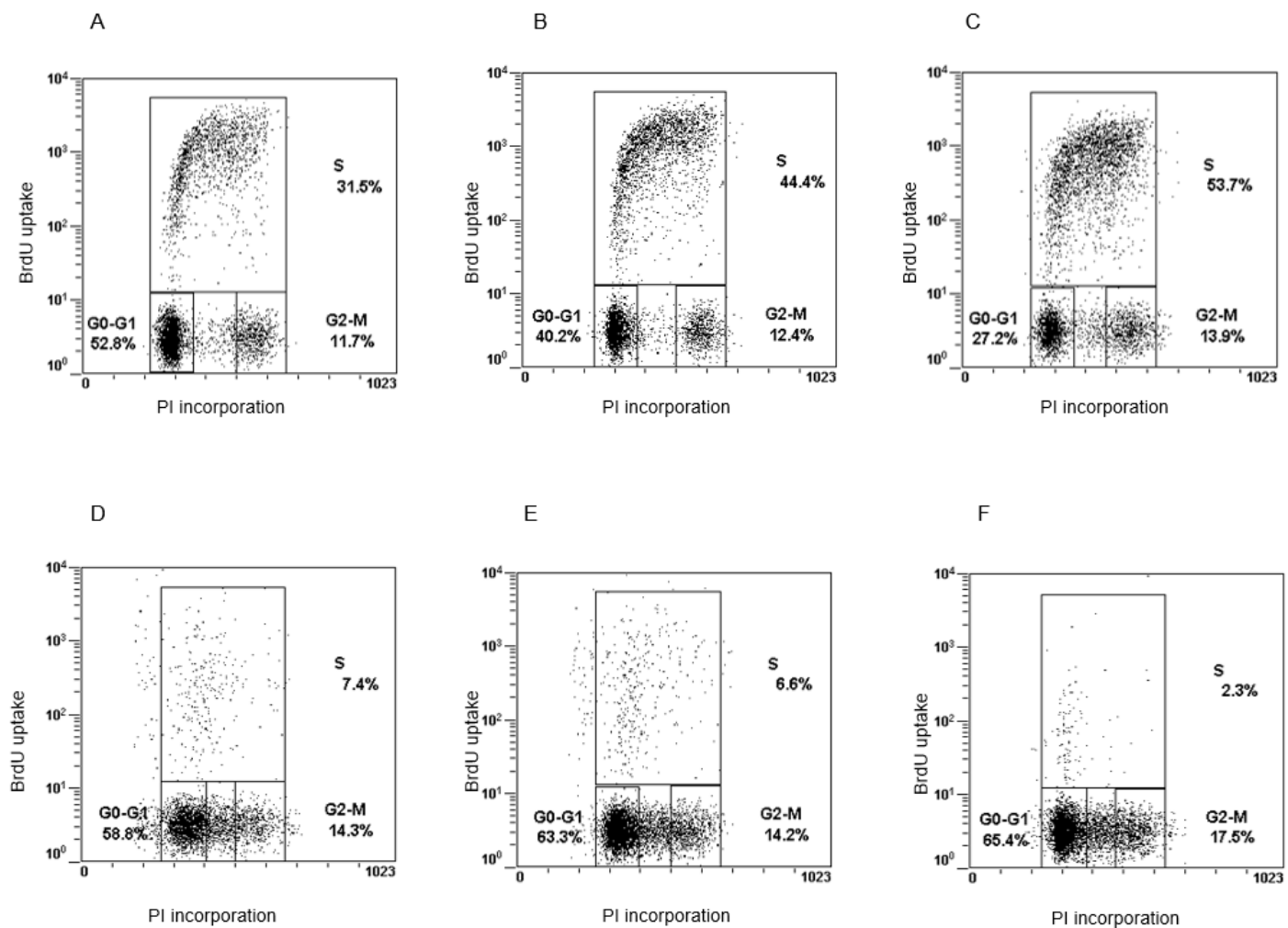

Figure 4. Cell cycle distribution, measured by bromodeoxyuridine (BrdU) uptake and propidium iodide (PI) staining, of A2780-Cis cells (control, A) and A2780-Cis cells treated with compound 3 at $5 \mathrm{nM}(\mathrm{B}), 10 \mathrm{nM}(\mathrm{C}), 50 \mathrm{nM}(\mathrm{D}), 100 \mathrm{nM}(\mathrm{E})$ and $500 \mathrm{nM}(\mathrm{F})$ for $24 \mathrm{~h}$.

The blocking of the cells in one of the phases of the cell cycle is often followed by fragmentation of the DNA and other morphological characteristics of apoptosis. The ability of 3 
to induce apoptosis was evaluated using a specific test that measures the cleaving of pro-caspases into active caspases. A2780 and A2780-Cis cells were treated for $24 \mathrm{~h}$ with different concentrations of $\mathbf{3}$, and induction of apoptosis was evaluated by measuring the activity of caspases 3 and 7. In Figure 5, a dose-dependent effect of $\mathbf{3}$ can clearly be seen on the two cell lines with a greater sensitivity in the cisplatin-resistant cells compared to the A2780 cell line. Unfortunately, an increase of active caspase-3 at the protein level was not observed, and a greater understanding of the mechanisms by which 3 induces cell death in an apoptotic and nonapoptotic manner is the focus of an ongoing study.

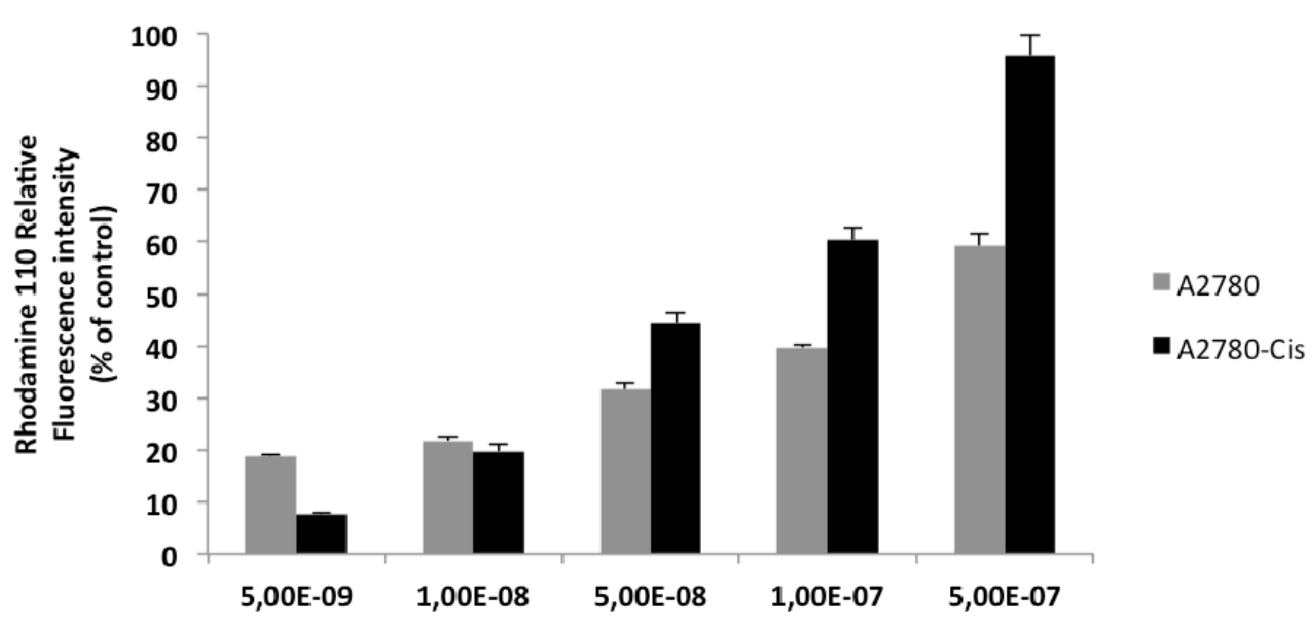

Figure 5. Apoptotic effects of 3 in A2780 and A2780-Cis cells. The results are expressed in the percentage of apoptotic cells detected following $24 \mathrm{~h}$ of treatment with 3 at different concentrations.

\section{Conclusions}

The ferrociphenol family is now a rich group of more than four hundred members, some of them endowed with unique antitumoral properties. All are characterized by the presence on their molecular skeleton of a redox motif of the \{ferrocenyl-ene-phenol\} type which can be activated 
to form a selective electrophilic QM in cancer cells. ${ }^{13-14}$ The importance of a functionalized chain on the olefin carbon of the ferrocenyl group, such as $-\left(\mathrm{CH}_{2}\right)_{3}-\mathrm{OH}$ in $\mathbf{2 a}$, has recently been shown to increase antiproliferative effects. We have shown here that the antitumoral effect can be improved still further with the help of specific cyclic-imides positioned at the end of the aforementioned - $\left(\mathrm{CH}_{2}\right)_{3}$-(heterocycle) chain, the most potent examples having been obtained with 3 (succinimide) and 4 (phthalimide) on ovarian epithelial cancer cells. In fact, with A2780-cis, a cell resistant to cisplatin, the $\mathrm{IC}_{50}$ values obtained are $49 \pm 3 \mathrm{nM}$ for 3 and $74 \pm 8 \mathrm{nM}$ for 4 , a remarkable result for a type of cancer whose resistance induced by carboplatin is a major therapeutic obstacle. The exceptional activity of these two cyclic-imidyl ferrociphenol species calls for an in-depth study of their chemical and biological mechanisms in the near future.

For the time being, we have started a few preliminary behavioral studies that may help establish directions for future exploration. The $\mathrm{IC}_{50}$ values obtained on healthy cells such as MRC5, normal human fibroblast cells, show that our compounds are more active, although in various degrees, on cancer cells. The selectivity factor SF gives an $\mathrm{IC}_{50}$ ratio for MRC5/A2780cis of 2 for $3,27.8$ for 4 and 28.5 for $2 \mathbf{a}$. It is therefore possible to take into account, where necessary, the balance between the highest antiproliferative activity with $\mathbf{3}$ and the more qualified SF values on healthy cells.

For 3 , it has been shown that the major metabolite resulting from chemical oxidation is a cyclic-imidyl QM using the ferrocene entity as an oxidizing intermediary. This mechanism is similar to previous observations, ${ }^{20-23}$ the difference being the noteworthy presence of the succinimido functionality whose exact role remains to be clarified. The cell cycle studied with this product shows the unusual effect of the stopping of the cycle in the $\mathrm{S}$ phase, often associated in these series with senescence, ${ }^{24-25}$ and the occurrence of apoptosis has been shown. 
The antiproliferative activity observed on these ovarian cells is quite similar, whether or not they are resistant to cisplatin. Compound $\mathbf{3}$ has the lowest $\mathrm{IC}_{50}$ values for the two categories, whereas 4 is twice as active on the resistant line than on A2780. The non-heterocyclic complexes $(11,2 a, 1 a)$ are also more active on the resistant line, but with $\mathrm{IC}_{50}$ values mostly around one order of magnitude higher, which still remains acceptable.

Comparison of the activity results of seven ferrociphenol compounds on K562 and doxorubicine-resistant $\mathrm{K} 562 \mathrm{R}$ shows that activity is less on the resistant line for five of the compounds. This may suggest that the compounds are partial substrates of $\mathrm{P}$ glycoprotein $(\mathrm{PgP})$ which is responsible for efflux-induced resistance to anticancer drugs. The two compounds that do not display these characteristics are 1a and $\mathbf{8}$, the only two compounds without a trimethylene carbon chain, but their $\mathrm{IC}_{50}$ values on $\mathrm{K} 562 \mathrm{R}$ are modest $(2.74 \mu \mathrm{M})$. Following on from these results, the unusual behavior of the two cyclic-imidyl molecules $\mathbf{3}$ and $\mathbf{4}$ is noteworthy. It may be remarked that if, in terms of $\mathrm{IC}_{50}$ values, 3 appears in general to be the more active, when other parameters such as SF are considered, the interest in $\mathbf{4}$ is increased. Biological studies are currently being carried out on the two species in parallel.

\section{Experimental section}

All reagents and solvents were obtained from commercial suppliers. THF was obtained by distillation from sodium/benzophenone. Thin layer chromatography (TLC) was performed on silica gel $60 \mathrm{GF}_{254}$. Column chromatography was performed on silica gel Merck $60(40-63 \mu \mathrm{m})$. All NMR experiments $\left({ }^{1} \mathrm{H},{ }^{13} \mathrm{C}\right)$ were carried out at room temperature on Bruker 300 and 400 NMR spectrometers. Assignments were made based on standard 1D and 2D methods, in particular HMBC, to assign ortho and meta phenolic resonances on compound 3. Mass 
spectrometry was performed with a Nermag R 10-10C spectrometer. HRMS measurements were performed on a Thermo Fischer LTQ-Orbitrap XL apparatus equipped with an electrospray source by IPCM (UMR 8232). Elemental analyses were performed by the microanalysis service of ICSN (Gif sur Yvette, France), purity of $\geqslant 95 \%$ was confirmed via elemental analysis for compound 3, 6c, 7, 8 and analytical HPLC for 9, 10. Cytotoxicity measurements were performed by Centre de Recherche de Gif, Institut de Chimie des Substances Naturelles, UPR 2301 du CNRS, Université Paris-Saclay, Gif-sur-Yvette Cedex, France.

General procedure for the synthesis of imides. A mixture of potassium carbonate and imide in dimethylformamide (DMF) was heated at $80{ }^{\circ} \mathrm{C}$ for $15 \mathrm{~min}$. Compound $\mathbf{6 a}$ or $\mathbf{6 b}$ was added and the stirring was continued at $80{ }^{\circ} \mathrm{C}$ overnight. The mixture was allowed to cool to room temperature, poured into a dilute hydrochloric acid solution, and extracted twice with diethyl ether, then the organic layer was dried on magnesium sulfate and concentrated under reduced pressure. The residue was purified by flash-chromatography with an ethyl acetate/cyclohexane mixture to afford the imide.

$N$-[4-Ferrocenyl-5,5-bis-(4-hydroxyphenyl)-pent-4-enyl]succinimide, 3. Following the general procedure for the synthesis of imides, potassium carbonate $(0.478 \mathrm{~g}, 3.5 \mathrm{mmoles})$, succinimide (0.457 g, 4.6 mmoles), compound 6a (1.09 g, 2.31 mmoles) furnished compound 3 as a yellow solid in a yield of 54\% (0.662 g). Mp: $225^{\circ} \mathrm{C}$ decomp. ${ }^{1} \mathrm{H}$ NMR (300 MHz, acetone$\left.\mathrm{d}_{6}\right): \delta 1.70-1.81\left(\mathrm{~m}, 2 \mathrm{H}, \mathrm{CH}_{2}\right), 2.56-2.64\left(\mathrm{~m}, 6 \mathrm{H}, 2 \mathrm{CH}_{2}\right.$ of succinimide $\left.+\mathrm{CH}_{2}-\mathrm{C}=\mathrm{C}\right), 3.38(\mathrm{t}, J=$ $\left.6.6 \mathrm{~Hz}, 2 \mathrm{H}, \mathrm{CH}_{2} \mathrm{~N}\right), 3.95\left(\mathrm{t}, J=1.9 \mathrm{~Hz}, 2 \mathrm{H}, \mathrm{C}_{5} \mathrm{H}_{4}\right), 4.10\left(\mathrm{t}, J=1.9 \mathrm{~Hz}, 2 \mathrm{H}, \mathrm{C}_{5} \mathrm{H}_{4}\right), 4.16(\mathrm{~s}, 5 \mathrm{H}$, Cp), $6.74\left(\mathrm{~d}, J=8.6 \mathrm{~Hz}, 2 \mathrm{H}, \mathrm{C}_{6} \mathrm{H}_{4}\right.$ ortho), 6.85 (d, $J=8.6 \mathrm{~Hz}, 2 \mathrm{H}, \mathrm{C}_{6} \mathrm{H}_{4}$ ortho), 6.91 (d, $J=8.6 \mathrm{~Hz}$, $2 \mathrm{H}, \mathrm{C}_{6} \mathrm{H}_{4}$ meta) $) 7.04$ (d, $J=8.6 \mathrm{~Hz}, 2 \mathrm{H}, \mathrm{C}_{6} \mathrm{H}_{4}$ meta $), 8.25$ (s, 1H, OH), 8.36 (s, 1H, OH). ${ }^{13} \mathrm{C}$ NMR (75 MHz, acetone- $\left.\mathrm{d}_{6}\right): \delta 29.4\left(2 \mathrm{CH}_{2}\right.$, succinimide), $30.8\left(\mathrm{CH}_{2}\right), 33.8\left(\mathrm{CH}_{2}\right), 39.7\left(\mathrm{CH}_{2}\right), 69.5$ 
$\left(2 \mathrm{CH}, \mathrm{C}_{5} \mathrm{H}_{4}\right), 70.7\left(7 \mathrm{CH}, \mathrm{Cp}+2 \mathrm{CH}, \mathrm{C}_{5} \mathrm{H}_{4}\right), 88.8\left(\mathrm{C}, \mathrm{C}_{5} \mathrm{H}_{4}\right), 116.5\left(2 \mathrm{CH}, \mathrm{C}_{6} \mathrm{H}_{4}\right.$ ortho $), 116.6(2 \mathrm{CH}$, $\mathrm{C}_{6} \mathrm{H}_{4}$ ortho $), 132.0$ (2CH, $\left.\mathrm{C}_{6} \mathrm{H}_{4 \text { meta }}\right), 132.4$ (2CH, $\left.\mathrm{C}_{6} \mathrm{H}_{4 \text { meta }}\right), 135.3$ (C), 137.7 (C), 137.9 (C), 140.2 (C), 157.3 (C), 157.5 (C), 178.6 (2CO). IR (KBr, v cm $\left.{ }^{-1}\right): 3421(\mathrm{OH}), 3096,2967,2936(\mathrm{CH}$, $\mathrm{CH}_{2}$ ), 1697 (CO). MS (ESI) m/z: $535[\mathrm{M}]^{+}$, 342, 279, 224, 143, 83. HRMS (ESI, $\mathrm{C}_{31} \mathrm{H}_{29} \mathrm{FeNO}_{4}$ : $[\mathrm{M}]^{+}$) calcd: 535.1446, found: 535.1460. Anal. Calcd for $\mathrm{C}_{31} \mathrm{H}_{29} \mathrm{FeNO}_{4}\left(\mathrm{H}_{2} \mathrm{O}\right)_{0.3}: \mathrm{C}, 68.85 ; \mathrm{H}$, 5.51; N, 2.58. Found: C, 68.76; H, 5.14; N, 2.37.

6-Chloro-2-ferrocenyl-1,1-bis-(4-hydroxyphenyl)-hex-1-ene, 6b. Titanium chloride (14.228 $\mathrm{g}, 8.24 \mathrm{~mL}, 75 \mathrm{mmoles}$ ) was added dropwise to a suspension of zinc powder (5.883 g, $90 \mathrm{mmoles}$ ) in dry THF $(500 \mathrm{~mL})$ at $10-20{ }^{\circ} \mathrm{C}$. The mixture was heated at reflux for 2 hours. A second solution was prepared by dissolving compound $5 \mathbf{b}$ (4.569 g, 15 mmoles) and 4,4'dihydroxybenzophenone $(3.222 \mathrm{~g}, 15 \mathrm{mmoles})$ in dry THF $(50 \mathrm{~mL})$. This latter solution was added dropwise to the first solution and then the reflux was continued overnight. After cooling to room temperature, the mixture was stirred with water and dichloromethane. The mixture was acidified with dilute hydrochloric acid until the dark color disappeared, and was then decanted. The aqueous layer was extracted with dichloromethane and the combination of organic layers was dried on magnesium sulfate. After concentration under reduced pressure, the crude product was chromatographed on silica gel column with dichloromethane/acetone $90 / 10$ as the eluent and crystallized from dichloromethane, to afford $\mathbf{6 b}$ in a yield of $60 \%$, as an orange solid. ${ }^{1} \mathrm{H}$ NMR (300 MHz, acetone- $\left.\mathrm{d}_{6}\right): \delta 1.61-1.74\left(\mathrm{~m}, 4 \mathrm{H}, \mathrm{CH}_{2}-\mathrm{CH}_{2}\right), 2.69\left(\mathrm{t}, J=7.4 \mathrm{~Hz}, 2 \mathrm{H}, \mathrm{CH}_{2}-\mathrm{C}=\mathrm{C}\right), 3.50$ $\left(\mathrm{t}, J=6.2 \mathrm{~Hz}, 2 \mathrm{H}, \mathrm{CH}_{2} \mathrm{Cl}\right), 3.96\left(\mathrm{t}, J=1.9 \mathrm{~Hz}, 2 \mathrm{H}, \mathrm{C}_{5} \mathrm{H}_{4}\right), 4.09\left(\mathrm{t}, J=1.9 \mathrm{~Hz}, 2 \mathrm{H}, \mathrm{C}_{5} \mathrm{H}_{4}\right), 4.15(\mathrm{~s}$, $5 \mathrm{H}, \mathrm{Cp}), 6.74\left(\mathrm{~d}, J=8.6 \mathrm{~Hz}, 2 \mathrm{H}, \mathrm{C}_{6} \mathrm{H}_{4}\right.$ ortho $), 6.85$ (d, $J=8.6 \mathrm{~Hz}, 2 \mathrm{H}, \mathrm{C}_{6} \mathrm{H}_{4}$ ortho), 6.91 (d, $J=8.6$ $\left.\mathrm{Hz}, 2 \mathrm{H}, \mathrm{C}_{6} \mathrm{H}_{4 \text { meta }}\right), 7.09$ (d, J=8.6 Hz, 2H, $\mathrm{C}_{6} \mathrm{H}_{4}$ meta) $), 8.28(\mathrm{~s}, 1 \mathrm{H}, \mathrm{OH}), 8.32(\mathrm{~s}, 1 \mathrm{H}, \mathrm{OH}) .{ }^{13} \mathrm{C}$ NMR (75 MHz, acetone-d $): \delta 28.4\left(\mathrm{CH}_{2}\right), 33.0\left(\mathrm{CH}_{2}\right), 34.2\left(\mathrm{CH}_{2}\right), 45.3\left(\mathrm{CH}_{2} \mathrm{Cl}\right), 68.4(2 \mathrm{CH}$, 
$\left.\mathrm{C}_{5} \mathrm{H}_{4}\right), 69.6(5 \mathrm{CH}, \mathrm{Cp}), 69.7\left(2 \mathrm{CH}, \mathrm{C}_{5} \mathrm{H}_{4}\right), 87.9\left(\mathrm{C}, \mathrm{C}_{5} \mathrm{H}_{4}\right), 115.5\left(2 \mathrm{CH}, \mathrm{C}_{6} \mathrm{H}_{4}\right.$ ortho $), 115.6(2 \mathrm{CH}$, $\mathrm{C}_{6} \mathrm{H}_{4}$ ortho $), 131.0$ (2CH, $\mathrm{C}_{6} \mathrm{H}_{4}$ meta $), 131.5$ (2CH, $\left.\mathrm{C}_{6} \mathrm{H}_{4 \text { meta }}\right), 134.5$ (C), 136.7 (C), 137.0 (C), 139.2 (C), $156.4(\mathrm{C}), 156.5(\mathrm{C})$. IR (KBr, $\left.v \mathrm{~cm}^{-1}\right): 3419(\mathrm{OH}), 2987,2952,2863\left(\mathrm{CH}, \mathrm{CH}_{2}\right)$. MS (EI, 70 eV) m/z: $486[\mathrm{M}]^{+}, 421,343,286,186$. HRMS (ESI, $\mathrm{C}_{28} \mathrm{H}_{27} \mathrm{ClFeO}_{2}:[\mathrm{M}]^{+}$) calcd: 486.1049, found: 486.1058 .

2-Ferrocenyl-1,1-bis-(4-hydroxyphenyl)-pent-1-ene, 6c. The same procedure as for $\mathbf{6 b}$ was used with commercially-available ferrocenyl propyl ketone 5c (1.28 g, 5 mmoles), titanium chloride (3.11 g, $1.8 \mathrm{~mL}, 16.4$ mmoles), zinc powder (2.0 g, 30.6 mmoles), 4,4'dihydroxybenzophenone (3.222 g, 15 mmoles), dry THF $(120+15 \mathrm{~mL})$, reflux 2 hours +2 hours to furnish compound $\mathbf{6 c}$ as an orange solid with a yield of $37 \%$. Mp: $186{ }^{\circ} \mathrm{C} .{ }^{1} \mathrm{H} \mathrm{NMR}(300 \mathrm{MHz}$, acetone- $\left.\mathrm{d}_{6}\right): \delta 0.85\left(\mathrm{t}, J=7.5 \mathrm{~Hz}, 3 \mathrm{H}, \mathrm{CH}_{3}\right), 1.45-1.60\left(\mathrm{~m}, 2 \mathrm{H}, \mathrm{CH}_{2}\right), 2.64(\mathrm{t}, J=8.0 \mathrm{~Hz}, 2 \mathrm{H}$, $\left.\mathrm{CH}_{2}\right), 3.94\left(\mathrm{t}, J=1.9 \mathrm{~Hz}, 2 \mathrm{H}, \mathrm{C}_{5} \mathrm{H}_{4}\right), 4.09\left(\mathrm{t}, J=1.9 \mathrm{~Hz}, 2 \mathrm{H}, \mathrm{C}_{5} \mathrm{H}_{4}\right), 4.15(\mathrm{~s}, 5 \mathrm{H}, \mathrm{Cp}), 6.74(\mathrm{~d}, J=$ $8.7 \mathrm{~Hz}, 2 \mathrm{H}, \mathrm{C}_{6} \mathrm{H}_{4}$ ortho), 6.85 (d, $J=8.7 \mathrm{~Hz}, 2 \mathrm{H}, \mathrm{C}_{6} \mathrm{H}_{4}$ ortho), 6.90 (d, $J=8.7 \mathrm{~Hz}, 2 \mathrm{H}, \mathrm{C}_{6} \mathrm{H}_{4}$ meta), $7.09\left(\mathrm{~d}, J=8.7 \mathrm{~Hz}, 2 \mathrm{H}, \mathrm{C}_{6} \mathrm{H}_{4}\right.$ meta $), 8.23(\mathrm{~s}, 1 \mathrm{H}, \mathrm{OH}), 8.26(\mathrm{~s}, 1 \mathrm{H}, \mathrm{OH}) .{ }^{13} \mathrm{C} \mathrm{NMR}(75 \mathrm{MHz}$, acetone- $\left.\mathrm{d}_{6}\right): \delta 15.4\left(\mathrm{CH}_{3}\right), 25.4\left(\mathrm{CH}_{2}\right), 38.4\left(\mathrm{CH}_{2}\right), 69.4\left(2 \mathrm{CH}, \mathrm{C}_{5} \mathrm{H}_{4}\right), 70.6(5 \mathrm{CH}, \mathrm{Cp}), 70.8$ $\left(2 \mathrm{CH}, \mathrm{C}_{5} \mathrm{H}_{4}\right), 89.3\left(\mathrm{C}, \mathrm{C}_{5} \mathrm{H}_{4}\right), 116.5\left(2 \times 2 \mathrm{CH}, \mathrm{C}_{6} \mathrm{H}_{4}\right.$ ortho $), 132.1\left(2 \mathrm{CH}, \mathrm{C}_{6} \mathrm{H}_{4}\right.$ meta $), 132.5(2 \mathrm{CH}$, $\left.\mathrm{C}_{6} \mathrm{H}_{4 \text { meta }}\right), 136.0$ (C), 138.1 (C), 138.3 (C), 140.0 (C), 157.4 (C), 157.5 (C). IR (KBr, v cm $\left.{ }^{-1}\right)$ : $3392(\mathrm{OH}), 2957,2869\left(\mathrm{CH}_{2}, \mathrm{CH}_{3}\right)$. MS (EI, $\left.70 \mathrm{eV}\right) \mathrm{m} / \mathrm{z}: 438[\mathrm{M}]^{+}, 395[\mathrm{M}-\mathrm{Pr}]^{+}, 373[\mathrm{M}-\mathrm{Cp}]^{+}$, $121[\mathrm{CpFe}]^{+}$. HRMS (FAB, $\mathrm{C}_{27} \mathrm{H}_{26} \mathrm{FeO}_{2}:[\mathrm{M}]^{+}$) calcd: 438.1283, found: 438.1287. Anal. Calcd for $\mathrm{C}_{27} \mathrm{H}_{26} \mathrm{FeO}_{2}$ : C, 73.98; H, 5.97. Found: C, 73.85; H, 5.91.

$N$-[4-Ferrocenyl-5,5-bis-(4-hydroxyphenyl)-pent-4-enyl]glutarimide, 7. Following the procedure used for 3 , potassium carbonate $(0.175 \mathrm{~g}, 1.3 \mathrm{mmoles})$, glutarimide $(0.191 \mathrm{~g}, 1.7$ mmoles), compound 6a ( $0.4 \mathrm{~g}, 0.85$ mmoles) gave compound 7 as an orange solid in a yield of 
$22 \%$ (0.10 g). Mp: $216{ }^{\circ} \mathrm{C}$ decomp. ${ }^{1} \mathrm{H}$ NMR (300 MHz, acetone- $\left.\mathrm{d}_{6}\right): \delta 1.60-1.76\left(\mathrm{~m}, 2 \mathrm{H}, \mathrm{CH}_{2}\right)$, 1.79-1.93 (m, 2H, $\left.\mathrm{CH}_{2}\right), 2.50-2.63\left(\mathrm{~m}, 6 \mathrm{H}\right.$, glutarimide $\left.+\mathrm{CH}_{2}\right), 3.65\left(\mathrm{t}, J=7.0 \mathrm{~Hz}, 2 \mathrm{H}, \mathrm{CH}_{2}\right), 3.92$ $\left(\mathrm{t}, J=1.9 \mathrm{~Hz}, 2 \mathrm{H}, \mathrm{C}_{5} \mathrm{H}_{4}\right), 4.06\left(\mathrm{t}, J=1.9 \mathrm{~Hz}, 2 \mathrm{H}, \mathrm{C}_{5} \mathrm{H}_{4}\right), 4.11(\mathrm{~s}, 5 \mathrm{H}, \mathrm{Cp}), 6.70(\mathrm{~d}, J=8.7 \mathrm{~Hz}, 2 \mathrm{H}$, $\mathrm{C}_{6} \mathrm{H}_{4}$ ortho), 6.81 (d, $J=8.5 \mathrm{~Hz}, 2 \mathrm{H}, \mathrm{C}_{6} \mathrm{H}_{4}$ ortho), 6.87 (d, $J=8.7 \mathrm{~Hz}, 2 \mathrm{H}, \mathrm{C}_{6} \mathrm{H}_{4}$ meta) 7.02 (d, $J=8.5$ $\mathrm{Hz}, 2 \mathrm{H}, \mathrm{C}_{6} \mathrm{H}_{4}$ meta) $, 8.24(\mathrm{~s}, 1 \mathrm{H}, \mathrm{OH}), 8.31(\mathrm{~s}, 1 \mathrm{H}, \mathrm{OH}) .{ }^{13} \mathrm{C}$ NMR $\left(75 \mathrm{MHz}\right.$, acetone- $\left.\mathrm{d}_{6}\right): \delta 17.8$ ( $\mathrm{CH}_{2}$, glutarimide), $29.6\left(\mathrm{CH}_{2}\right), 33.0\left(\mathrm{CH}_{2}\right), 33.2\left(2 \mathrm{CH}_{2}\right.$, glutarimide $), 39.6\left(\mathrm{CH}_{2}\right), 68.6(2 \mathrm{CH}$, $\left.\mathrm{C}_{5} \mathrm{H}_{4}\right), 69.9$ (5CH, Cp), $70.0\left(2 \mathrm{CH}, \mathrm{C}_{5} \mathrm{H}_{4}\right), 88.1\left(\mathrm{C}, \mathrm{C}_{5} \mathrm{H}_{4}\right), 115.7\left(2 \mathrm{CH}, \mathrm{C}_{6} \mathrm{H}_{4}\right.$ ortho $), 115.9$ (2CH, $\mathrm{C}_{6} \mathrm{H}_{4}$ ortho), 131.2 (2CH, $\mathrm{C}_{6} \mathrm{H}_{4}$ meta), 131.7 (2CH, $\mathrm{C}_{6} \mathrm{H}_{4}$ meta), 134.6 (C), 137.0 (C), 137.3 (C), 139.3 (C), $156.6(\mathrm{C}), 156.7(\mathrm{C}), 173.0(2 \mathrm{CO})$. IR $\left(\mathrm{KBr}, v \mathrm{~cm}^{-1}\right)$ : $3358(\mathrm{OH}), 1723(\mathrm{CO})$. HRMS (ESI, $\left.\mathrm{C}_{32} \mathrm{H}_{31} \mathrm{FeNNaO}_{4}: \quad[\mathrm{M}+\mathrm{Na}]^{+}\right)$calcd: 572.1500, found: 572.1495. Anal. Calcd for $\mathrm{C}_{32} \mathrm{H}_{31} \mathrm{FeNO}_{4}\left(\mathrm{H}_{2} \mathrm{O}\right)_{0.5}:$ C, 68.82; H, 5.77; N, 2.50. Found: C, 68.86; H, 5.46; N, 2.49.

$N$-[5-Ferrocenyl-6,6-bis-(4-hydroxyphenyl)-hex-5-enyl]succinimide, 8. Likewise, potassium carbonate ( $0.415 \mathrm{~g}, 3$ mmoles), succinimide ( $0.396 \mathrm{~g}, 4$ mmoles), compound $6 \mathbf{b}$ ( 0.974 g, 2 mmoles) gave compound 8 as an orange solid in a yield of 58\% (0.632 g). mp: $207{ }^{\circ} \mathrm{C}$ decomp. ${ }^{1} \mathrm{H}$ NMR $\left(300 \mathrm{MHz}\right.$, acetone- $\left.\mathrm{d}_{6}\right): \delta$ 1.42-1.54 (m, 4H, $\left.\mathrm{CH}_{2}-\mathrm{CH}_{2}\right), 2.66-2.71(\mathrm{~m}, 6 \mathrm{H}$, succinimide $\left.+\mathrm{CH}_{2}-\mathrm{C}=\mathrm{C}\right), 3.35\left(\mathrm{t}, J=6.6 \mathrm{~Hz}, 2 \mathrm{H}, \mathrm{CH}_{2} \mathrm{~N}\right), 3.95\left(\mathrm{t}, J=1.9 \mathrm{~Hz}, 2 \mathrm{H}, \mathrm{C}_{5} \mathrm{H}_{4}\right), 4.10(\mathrm{t}, J$ $\left.=1.9 \mathrm{~Hz}, 2 \mathrm{H}, \mathrm{C}_{5} \mathrm{H}_{4}\right), 4.17(\mathrm{~s}, 5 \mathrm{H}, \mathrm{Cp}), 6.73\left(\mathrm{~d}, J=8.6 \mathrm{~Hz}, 2 \mathrm{H}, \mathrm{C}_{6} \mathrm{H}_{4}\right.$ ortho $), 6.84(\mathrm{~d}, J=8.6 \mathrm{~Hz}, 2 \mathrm{H}$, $\mathrm{C}_{6} \mathrm{H}_{4}$ ortho), 6.89 (d, $\left.J=8.6 \mathrm{~Hz}, 2 \mathrm{H}, \mathrm{C}_{6} \mathrm{H}_{4 \text { meta }}\right), 7.08$ (d, $\left.J=8.6 \mathrm{~Hz}, 2 \mathrm{H}, \mathrm{C}_{6} \mathrm{H}_{4 \text { meta }}\right), 8.25$ (s, $\left.1 \mathrm{H}, \mathrm{OH}\right)$, $8.30(\mathrm{~s}, 1 \mathrm{H}, \mathrm{OH}) .{ }^{13} \mathrm{C}$ NMR $\left(75 \mathrm{MHz}\right.$, acetone-d $\left.\mathrm{d}_{6}\right): \delta 28.1\left(2 \mathrm{CH}_{2}\right), 28.3\left(2 \mathrm{CH}_{2}\right), 34.6\left(\mathrm{CH}_{2}\right), 38.4$ $\left(\mathrm{CH}_{2}\right), 68.3\left(2 \mathrm{CH}, \mathrm{C}_{5} \mathrm{H}_{4}\right), 69.5(5 \mathrm{CH}, \mathrm{Cp}), 69.7\left(2 \mathrm{CH}, \mathrm{C}_{5} \mathrm{H}_{4}\right), 88.2\left(\mathrm{C}, \mathrm{C}_{5} \mathrm{H}_{4}\right), 115.4\left(2 \mathrm{CH}, \mathrm{C}_{6} \mathrm{H}_{4}\right.$ ortho), 115.5 (2CH, $\mathrm{C}_{6} \mathrm{H}_{4}$ ortho $), 130.9$ (2CH, $\mathrm{C}_{6} \mathrm{H}_{4}$ meta), 131.4 (2CH, $\left.\mathrm{C}_{6} \mathrm{H}_{4 \text { meta }}\right), 134.6$ (C), 136.7 (C), 137.0 (C), 139.0 (C), 156.3 (C), 156.4 (C), 177.7 (2CO). IR (KBr, v cm $\left.{ }^{-1}\right): 3393(\mathrm{OH}), 3096$, 3023, 2940, $2879\left(\mathrm{CH}, \mathrm{CH}_{2}\right), 1681$ (CO). MS (EI, $\left.70 \mathrm{eV}\right) \mathrm{m} / \mathrm{z}: 549[\mathrm{M}]^{+}, 484$ [M-Cp] $^{+}, 442,382$, 
343, 286, 186. HRMS (ESI, $\mathrm{C}_{32} \mathrm{H}_{31} \mathrm{FeNO}_{4}:[\mathrm{M}]^{+}$) calcd: 549.1602, found: 549.1622. Anal. Calcd for $\mathrm{C}_{32} \mathrm{H}_{31} \mathrm{FeNO}_{4}\left(\mathrm{H}_{2} \mathrm{O}\right): \mathrm{C}, 67.73 ; \mathrm{H}, 5.85 ; \mathrm{N}, 2.46$. Found: $\mathrm{C}, 67.33 ; \mathrm{H}, 5.53 ; \mathrm{N}, 2.28$.

5-(2'-Carboxypropamido)-2-ferrocenyl-1,1-bis-(4-hydroxyphenyl)-pent-1-ene, 9. Imide 3 (3.18 g, 5.94 mmoles) was dissolved into an ethanol/water solution $(300 \mathrm{~mL} / 150 \mathrm{~mL})$ and sodium hydroxide (6.2 g, 155 mmoles) was added. The solution was stirred overnight at room temperature, then was poured into water and acidified $(\mathrm{HCl})$ in order to protonate phenolates. Then the $\mathrm{pH}$ was adjusted to 5-6 with sodium hydrogen carbonate in order to deprotonate the carboxylic function only. Ethyl acetate was added, the organic layer was discarded and the aqueous layer was washed with ethyl acetate, then was acidified $(\mathrm{HCl})$. Acid $\mathbf{9}$ was extracted twice with ethyl acetate, then the solution was concentrated under reduced pressure. Acid $\mathbf{9}$ was obtained as an orange solid in a yield of $98 \%$ and was recrystallized from an acetone/dichloromethane solution. Mp: $198{ }^{\circ} \mathrm{C} .{ }^{1} \mathrm{H}$ NMR (300 MHz, acetone- $\left.\mathrm{d}_{6}\right)$ : $\delta$ 1.61-1.74 (m, 2H, $\left.\mathrm{CH}_{2}\right), 2.43\left(\mathrm{t}, J=6.6 \mathrm{~Hz}, 2 \mathrm{H}, \mathrm{CH}_{2}\right), 2.57\left(\mathrm{t}, J=6.6 \mathrm{~Hz}, 2 \mathrm{H}, \mathrm{CH}_{2}\right), 2.62-2.71\left(\mathrm{~m}, 2 \mathrm{H}, \mathrm{CH}_{2}-\right.$ $\mathrm{C}=\mathrm{C}), 3.10\left(\mathrm{t}, J=6.6 \mathrm{~Hz}, 2 \mathrm{H}, \mathrm{CH}_{2} \mathrm{~N}\right), 3.93\left(\mathrm{t}, J=1.9 \mathrm{~Hz}, 2 \mathrm{H}, \mathrm{C}_{5} \mathrm{H}_{4}\right), 4.05(\mathrm{t}, J=1.9 \mathrm{~Hz}, 2 \mathrm{H}$, $\left.\mathrm{C}_{5} \mathrm{H}_{4}\right), 4.12(\mathrm{~s}, 5 \mathrm{H}, \mathrm{Cp}), 6.70\left(\mathrm{~d}, J=8.5 \mathrm{~Hz}, 2 \mathrm{H}, \mathrm{C}_{6} \mathrm{H}_{4}\right.$ ortho $), 6.82$ (d, $J=8.5 \mathrm{~Hz}, 2 \mathrm{H}, \mathrm{C}_{6} \mathrm{H}_{4}$ ortho), $6.86\left(\mathrm{~d}, J=8.5 \mathrm{~Hz}, 2 \mathrm{H}, \mathrm{C}_{6} \mathrm{H}_{4}\right.$ meta), 6.98 (s broad, $\left.1 \mathrm{H}, \mathrm{NH}\right), 7.05$ (d, $J=8.5 \mathrm{~Hz}, 2 \mathrm{H}, \mathrm{C}_{6} \mathrm{H}_{4}$ meta). ${ }^{13} \mathrm{C}$ NMR $(75 \mathrm{MHz}$, acetone-d 6$): \delta 29.2\left(\mathrm{CH}_{2}\right), 31.2\left(\mathrm{CH}_{2}\right), 31.5\left(\mathrm{CH}_{2}\right), 32.9\left(\mathrm{CH}_{2}\right), 40.1\left(\mathrm{CH}_{2}\right)$, $68.7\left(2 \mathrm{CH}, \mathrm{C}_{5} \mathrm{H}_{4}\right), 69.9$ (5CH, Cp), $70.0\left(2 \mathrm{CH}, \mathrm{C}_{5} \mathrm{H}_{4}\right), 88.3\left(\mathrm{C}, \mathrm{C}_{5} \mathrm{H}_{4}\right), 115.8\left(2 \mathrm{CH}, \mathrm{C}_{6} \mathrm{H}_{4}\right.$ ortho), 115.9 (2CH, $\mathrm{C}_{6} \mathrm{H}_{4}$ ortho), 131.3 (2CH, $\mathrm{C}_{6} \mathrm{H}_{4}$ meta), 131.7 (2CH, $\mathrm{C}_{6} \mathrm{H}_{4}$ meta), 134.7 (C), 137.0 (C), 137.3 (C), 139.4 (C), 156.7 (C), 156.8 (C), 172.6 (CO), 174.1 (CO). IR (ATR, $v \mathrm{~cm}^{-1}$ ): 2970 $(\mathrm{OH}), 1727$ (CO), $1711(\mathrm{CO})$. HRMS (ESI, $\mathrm{C}_{31} \mathrm{H}_{31} \mathrm{FeNNaO}_{5}$ : [M+Na] $]^{+}$) calcd: 576.1449, found: 576.1443. 
5-(o-Carboxybenzamido)-2-ferrocenyl-1,1-bis-(4-hydroxyphenyl)-pent-1-ene, $\quad 10 . \quad$ The same procedure as for 9 was used with imide 4 ( $0.226 \mathrm{~g}, 0.39 \mathrm{mmoles})$, sodium hydroxide $(0.24 \mathrm{~g}$, 6 mmoles), ethanol $(20 \mathrm{~mL})$, water $(10 \mathrm{~mL})$ to furnish acid $\mathbf{1 0}$ as an orange solid with a yield of 78 \%. Mp: $175^{\circ} \mathrm{C} .{ }^{1} \mathrm{H}$ NMR (300 MHz, DMSO-d $\left.{ }_{6}\right): \delta 1.61-1.77\left(\mathrm{~m}, 2 \mathrm{H}, \mathrm{CH}_{2}\right), 2.51-2.60(\mathrm{~m}, 2 \mathrm{H}$, $\left.\mathrm{CH}_{2}\right), 3.08\left(\mathrm{q}, J=6.5 \mathrm{~Hz}, 2 \mathrm{H}, \mathrm{CH}_{2} \mathrm{~N}\right), 3.85\left(\mathrm{t}, J=1.9 \mathrm{~Hz}, 2 \mathrm{H}, \mathrm{C}_{5} \mathrm{H}_{4}\right), 4.07(\mathrm{t}, J=1.9 \mathrm{~Hz}, 2 \mathrm{H}$, $\left.\mathrm{C}_{5} \mathrm{H}_{4}\right), 4.11(\mathrm{~s}, 5 \mathrm{H}, \mathrm{Cp}), 6.64\left(\mathrm{~d}, J=8.3 \mathrm{~Hz}, 2 \mathrm{H}, \mathrm{C}_{6} \mathrm{H}_{4}\right.$ ortho $), 6.73$ (d, $J=8.3 \mathrm{~Hz}, 2 \mathrm{H}, \mathrm{C}_{6} \mathrm{H}_{4}$ ortho), $6.80\left(\mathrm{~d}, J=8.3 \mathrm{~Hz}, 2 \mathrm{H}, \mathrm{C}_{6} \mathrm{H}_{4}\right.$ meta), 6.98 (d, $J=8.3 \mathrm{~Hz}, 2 \mathrm{H}, \mathrm{C}_{6} \mathrm{H}_{4}$ meta) 7.32 (d, $J=7.4 \mathrm{~Hz}, 1 \mathrm{H}$, $\left.\mathrm{H}_{\text {arom }}\right), 7.49$ (t, $\left.J=7.4 \mathrm{~Hz}, 1 \mathrm{H}, \mathrm{H}_{\text {arom }}\right), 7.58\left(\mathrm{t}, J=7.5 \mathrm{~Hz}, 1 \mathrm{H}, \mathrm{H}_{\text {arom }}\right), 7.74(\mathrm{~d}, J=7.5 \mathrm{~Hz}, 1 \mathrm{H}$, $\mathrm{H}_{\text {arom }}$ ), 8.25 (s broad, 1H, NH), 9.26 (s, 1H, OH), 9.31 (s, 1H, OH). ${ }^{13} \mathrm{C}$ NMR (75 MHz, DMSO$\left.\mathrm{d}_{6}\right): \delta 30.3\left(\mathrm{CH}_{2}\right), 31.9\left(\mathrm{CH}_{2}\right), 39.8\left(\mathrm{CH}_{2}\right), 67.7\left(2 \mathrm{CH}, \mathrm{C}_{5} \mathrm{H}_{4}\right), 68.8\left(2 \mathrm{CH}, \mathrm{C}_{5} \mathrm{H}_{4}\right), 69.0(5 \mathrm{CH}, \mathrm{Cp})$, $86.6\left(\mathrm{C}, \mathrm{C}_{5} \mathrm{H}_{4}\right), 115.0\left(2 \times 2 \mathrm{CH}, \mathrm{C}_{6} \mathrm{H}_{4}\right.$ ortho $), 127.6\left(\mathrm{CH}_{\text {arom }}\right), 129.0\left(\mathrm{CH}_{\text {arom }}\right), 129.1\left(\mathrm{CH}_{\text {arom }}\right), 129.9$ (2CH, $\mathrm{C}_{6} \mathrm{H}_{4}$ meta $), 130.3$ (2CH, $\mathrm{C}_{6} \mathrm{H}_{4}$ meta) $130.8(\mathrm{C}), 131.0\left(\mathrm{CH}_{\text {arom }}\right), 133.3(\mathrm{C}), 135.3$ (C), 135.7 (C), 138.0 (C), 138.6 (C), 155.57 (C), 155.64 (C), 168.0 (CO), 168.2 (CO). IR (ATR, v cm ${ }^{-1}$ ): 2970 (OH), 1738 (CO). HRMS (ESI, $\mathrm{C}_{35} \mathrm{H}_{31} \mathrm{FeNNaO}_{5}$ : $[\mathrm{M}+\mathrm{Na}]^{+}$) calcd: 624.1449, found: 624.1445 .

X-Ray crystal structure determination. Single crystals were selected, mounted and transferred into a cold nitrogen gas stream. Intensity data was collected with Bruker Kappa-APEX2 systems using micro-source $\mathrm{Cu}-\mathrm{K} \alpha$ radiation. Unit-cell parameters, data collection strategy, integration and absorption correction were carried out with the Bruker APEX2 suite of programs. Structures were solved with SHELXT-2014 ${ }^{50}$ and refined anisotropically by full-matrix least-squares methods with SHELXL-2014 ${ }^{50}$ using the WinGX suite. ${ }^{51}$ Relevant data have been deposited at the Cambridge Crystallographic Data Centre with numbers CCDC 1542075 and 1542077 and can be obtained free of charge via www.ccdc.cam.ac.uk. 
Electrochemical oxidation of 3 and 4. Cyclic voltammograms (CVs) were obtained using a three electrode cell with a $0.5 \mathrm{~mm}$ Pt working electrode, stainless steel rod counter electrode, and $\mathrm{Ag} / \mathrm{AgCl}$ ethanol reference electrode, with an $\mu$-Autolab 3 potentiostat driven by GPES software (General Purpose Electrochemical System, Version 4.8, EcoChemie B.V., Utrecht, the Netherlands). Solutions consisted of $5 \mathrm{~mL} \mathrm{CH} \mathrm{CH}_{3} \mathrm{CN}$, approximately $1 \mathrm{mM}$ analyte, and $0.1 \mathrm{M}$ $\mathrm{Bu}_{4} \mathrm{NPF}_{6}$ supporting electrolyte. Scan rate of CVs was $200 \mathrm{mV} / \mathrm{s}$.

Lipophilicity. Measurements of the octanol/water partition coefficient (log Po/w) were made by the HPLC technique. Measurement of the chromatographic capacity factors $(\mathrm{k})$ for each molecule was done at various concentrations in the range of $95-75 \%$ methanol containing $0.25 \%(\mathrm{v} / \mathrm{v}) 1$ octanol and an aqueous phase consisting of $0.15 \%(\mathrm{v} / \mathrm{v}) \mathrm{n}$-decylamine in the buffering agent MOPS (3-morpholinopropane-1-sulfonic acid, prepared in 1-octanol saturated water) adjusted to $\mathrm{pH}$ 7.4. These capacity factors $\left(\mathrm{k}^{\prime}\right)$ are extrapolated to $100 \%$ of the aqueous component given the value of $\mathrm{k}^{\prime} \mathrm{w}$. The $\log \mathrm{Po} / \mathrm{w}$ is obtained by the formula $\log \mathrm{Po} / \mathrm{w}=0.13418+0.98452 \log \mathrm{k}^{\prime}$.

Cell Culture and Proliferation Assay. Cancer cell lines were obtained from the American Type Culture Collection (Rockville, MD, USA) or from the European collection of cell culture (ECACC, England) and were cultured according to the supplier's instructions. Human HCT-116 colorectal carcinoma and SK-OV-3 ovary carcinoma were grown in Gibco McCoy's 5A supplemented with $10 \%$ fetal calf serum (FCS) and $1 \%$ glutamine. K562 and K562R myelogenous leukemia, A2780 and A2780-Cis ovarian carcinoma cells were grown in RPMI 1640 supplemented with $10 \%$ fetal calf serum (FCS) and 1\% glutamine. Mia-Paca2 carcinoma cells were grown in Gibco medium DMEM supplemented with $10 \%$ fetal calf serum (FCS) and $1 \%$ glutamine. Cells were maintained at $37{ }^{\circ} \mathrm{C}$ in a humidified atmosphere containing $5 \% \mathrm{CO}_{2}$. Cell growth inhibition was determined by an MTS assay according to the manufacturer's 
instructions (Promega, Madison, WI, USA). Briefly, the cells were seeded in 96-well plates (2.5 $\times 10^{3}$ cells/well) containing $100 \mu \mathrm{L}$ of growth medium. After $24 \mathrm{~h}$ of culture, the cells were treated with the tested compounds at 10 different final concentrations. After $72 \mathrm{~h}$ of incubation, $20 \mu \mathrm{L}$ of CellTiter $96{ }^{\circledR} \mathrm{AQ}_{\text {ueous }}$ One Solution Reagent was added for $2 \mathrm{~h}$ before recording absorbance at $490 \mathrm{~nm}$ with a spectrophotometric plate reader PolarStar Omega (BMG Labtech, USA). The dose-response curves were plotted with Graph Prism software and the $\mathrm{IC}_{50}$ values were calculated using the Graph Prism software from polynomial curves (four or five-parameter logistic equations).

MDA-MB-231: Stock solutions (10 $\mathrm{mM})$ of the compounds to be tested were prepared in DMSO and were kept at $-20{ }^{\circ} \mathrm{C}$ in the dark. Serial dilutions in Dulbecco's modified eagle medium (DMEM) without phenol red/Glutamax I were prepared just prior to use. DMEM without phenol red, Glutamax I and fetal bovine serum were purchased from Gibco; MDA-MB-231 cells were obtained from ATCC (Manassas, VA, USA). Cells were maintained in a monolayer culture in DMEM with phenol red/Glutamax I supplemented with $9 \%$ fetal bovine serum at $37{ }^{\circ} \mathrm{C}$ in a $5 \%$ $\mathrm{CO}_{2} /$ air-humidified incubator. For proliferation assays, MDA-MB-231 cells were plated in $1 \mathrm{~mL}$ of DMEM without phenol red, supplemented with $9 \%$ decomplemented and hormone-depleted fetal bovine serum, $1 \%$ kanamycin, $1 \%$ Glutamax I and incubated. The following day(D0), $1 \mathrm{~mL}$ of the same medium containing the compounds to be tested was added to the plates. After 3 days (D3) the incubation medium was removed and $2 \mathrm{~mL}$ of the fresh medium containing the compounds was added. At different days (D4, D5), the protein content of each well was quantified by methylene blue staining as follows: cell monolayers were fixed for $1 \mathrm{~h}$ at room temperature with methylene blue (1mg mL-1 in 50:50 water/MeOH mixture), then washed with water. After addition of $\mathrm{HCl}(0.1 \mathrm{M}, 2 \mathrm{~mL})$, the plate was incubated for $1 \mathrm{~h}$ at $37^{\circ} \mathrm{C}$ and then the absorbance of each well (4 wells for each concentration) was measured at $655 \mathrm{~nm}$ with a Biorad 
spectrophotometer. The results are expressed as the percentage of proteins versus the control. Two independent experiments, run in quadruplicate, were performed.

Cell Cycle Analysis. Exponentially growing A2780-Cis cancer cells were incubated with the tested compound or DMSO for $24 \mathrm{~h}$. Cell-cycle profiles were determined by flow cytometry on a FC500 flow cytometer (Beckman-Coulter, France) as described previously. ${ }^{52}$

Apoptosis Assay. Apoptosis was measured by the Apo-one homogeneous caspase-3/7 assay (Promega Co, WI) according to the manufacturer's recommendations. Briefly, cells were subcultured on a 96 -well plate with $5 \times 10^{4}$ cells/well in $50 \mu \mathrm{L}$ medium. After $24 \mathrm{~h}$ of culture, the cells were supplemented with $50 \mu \mathrm{L}$ of medium containing different concentrations of compound $6(5,10,50,100$ and $500 \mathrm{nM})$ or $0.1 \%$ DMSO (as negative control). The treated cells were incubated for $24 \mathrm{~h}$, each well then received $100 \mu \mathrm{L}$ of a mixture of caspase substrate and Apo-one caspase 3/7 buffer. After $6 \mathrm{~h}$ of incubation, the fluorescence of sample was measured using a PolarStar Omega microtiter plate fluorimeter (BMG Labtech, USA) at $527 \mathrm{~nm}$.

\title{
Supporting Information Available
}

Crystallographic Data for 3 and 9, molecular formula strings of related compounds, ${ }^{1} \mathrm{H}$ NMR spectrum of 3-QM in acetone- $d_{6}$. Mass spectrometry of 3, $\mathbf{6 b}$ and $\mathbf{8}$. This material is available free of charge via the Internet at http://pubs.acs.org.

\author{
AUTHOR INFORMATION \\ Corresponding Authors: \\ Phone: +33 33 144276697, gerard.jaouen@upmc.fr; + 33 144276699, pascal.pigeon@,chimie- \\ paristech.fr.
}


Dr P. Pascal and Dr Y. Wang equally contributed to this work.

\title{
ACKNOWLEDGEMENTS
}

The authors acknowledge Geoffrey Gontard of the Institut Parisien de Chimie Moléculaire for all X-ray diffraction studies, PSL, Feroscan and PGG for financial support of Y. W., Barbara McGlinchey for editorial assistance, and Dr F. Mechta-Grigoriou, Curie Hospital, for helpful discussions.

\begin{abstract}
ABBREVIATIONS USED
EOC, epithelial ovarian cancer; ROS, reactive oxygen species; QM, quinone methide; $\mathrm{IC}_{50}$, half inhibitory concentration; AP1, activator protein 1; IL-6, interleukin-6; IL-8, interleukin-8; A2780-Cis, A2780 resistant to cisplatin; SF, selectivity factor; BrDU, bromodeoxyuridine; PI, propidium iodide; PgP, P glycoprotein.
\end{abstract}

\section{References:}

1. Jaouen, G.; Metzler-Nolte, N. Medicinal Organometallic Chemistry, Vol. 32. Springerlink ed.: 2010; Vol. 32.

2. Zhang, P.; Sadler, P. J. Advances in the design of organometallic anticancer complexes. J. Organomet. Chem. 2017, 839, 5-14.

3. Kowalski, K. Ferrocenyl-nucleobase complexes: synthesis, chemistry and applications. Coord. Chem. Rev. 2016, 317, 132-156.

4. Salas, P. F.; Herrmann, C.; Cawthray, J. F.; Nimphius, C.; Kenkel, A.; Chen, J.; de Kock, C.; Smith, P. J.; Patrick, B. O.; Adam, M. J.; Orvig, C. Structural characteristics of chloroquine- 
bridged ferrocenophane analogues of ferroquine may obviate malaria drug-resistance mechanisms. J. Med. Chem. 2013, 56 (4), 1596-1613.

5. Amin, J.; Chuckowree, I. S.; Wang, M.; Tizzard, G. J.; Coles, S. J.; Spencer, J. Synthesis of Oxindole-based bioorganometallic kinase inhibitors incorporating one or more ferrocene groups. Organometallics 2013, 32 (20), 5818-5825.

6. Braga, S. S.; Silva, A. M. S. A new age for iron: antitumoral ferrocenes. Organometallics 2013, 32 (20), 5626-5639.

7. Wani, W. A.; Baig, U.; Shreaz, S.; Shiekh, R. A.; Iqbal, P. F.; Jameel, E.; Ahmad, A.; Mohd-Setapar, S. H.; Mushtaque, M.; Huna, L. T. Recent advances in iron complexes as potential anticancer agents. New J. Chem. 2016, 40 (2), 1063-1090.

8. Balaji, B.; Balakrishnan, B.; Perumalla, S.; Karande, A. A.; Chakravarty, A. R. Mitochondria-targeting photocytotoxic ferrocenyl conjugates of $\mathrm{N}$-alkylpyridinium salts. Eur. $J$. Inorg. Chem. 2015, 8, 1398-1407.

9. Daum, S.; Chekhun, V. F.; Todor, I. N.; Lukianova, N. Y.; Shvets, Y. V.; Sellner, L.; Putzker, K.; Lewis, J.; Zenz, T.; de Graaf, I. A. M.; Groothuis, G. M. M.; Casini, A.; Zozulia, O.; Hampel, F.; Mokhir, A. Improved synthesis of N-benzylaminoferrocene-based prodrugs and evaluation of their toxicity and antileukemic activity. J. Med. Chem. 2015, 58 (4), 2015-2024.

10. Mooney, A.; Tiedt, R.; Maghoub, T.; O'Donovan, N.; Crown, J.; White, B.; Kenny, P. T. M. Structure-activity relationship and mode of action of N-(6-ferrocenyl-2-naphthoyl) dipeptide ethyl esters: novel organometallic anticancer compounds. J. Med. Chem. 2012, 55 (11), 54555466.

11. Deepthi, S. B.; Trivedi, R.; Giribabu, L.; Sujitha, P.; Kumar, C. G. Effect of amidetriazole linkers on the electrochemical and biological properties of ferrocene-carbohydrate conjugates. Dalton Trans. 2013, 42 (4), 1180-1190. 
12. Dubar, F.; Slomianny, C.; Khalife, J.; Dive, D.; Kalamou, H.; Guérardel, Y.; Grellier, P.; Biot, C. The ferroquine antimalarial conundrum: redox activation and reinvasion inhibition. Angew. Chem. Int. Ed. 2013, 52 (30), 7690-7693.

13. Jaouen, G.; Top, S. The Ferrocifen Family as Potent and Selective Antitumor Compounds: Mechanisms of Action. In Advances in Organometallic Chemistry and Catalysis, Pombeiro, A. J. L., Ed.; Wiley \& Sons: Hoboken, NJ, USA, 2014; pp 561-580.

14. Jaouen, G.; Vessieres, A.; Top, S. Ferrocifen type anti cancer drugs. Chem. Soc. Rev. 2015, 44 (24), 8802-8817.

15. Jaouen, G.; Pigeon, P.; Top, S. Metallocene Derivatives with Anticancer Activity. WO 2015063201, EP2868664, 2014.

16. Batista, L.; Gruosso, T.; Mechta-Grigoriou, F. Ovarian cancer emerging subtypes: role of oxidative stress and fibrosis in tumour development and response to treatment. Int. J. Biochem. Cell Biol. 2013, 45 (6), 1092-1098.

17. Gruosso, T.; Garnier, C.; Abelanet, S.; Kieffer, Y.; Lemesre, V.; Bellanger, D.; Bieche, I.; Marangoni, E.; Sastre-Garau, X.; Mieulet, V.; Mechta-Grigoriou, F. MAP3K8/TPL-2/COT is a potential predictive marker for MEK inhibitor treatment in high-grade serous ovarian carcinomas. Nat. Commun. 2015, 6, 8583.

18. Batista, L.; Bourachot, B.; Mateescu, B.; Reyal, F.; Mechta-Grigoriou, F. Regulation of miR-200c/141 expression by intergenic DNA-looping and transcriptional read-through. Nat. Commun. 2016, 7, 8959.

19. Lu, C.; Heldt, J.-M.; Guille-Collignon, M.; Lemaitre, F.; Jaouen, G.; Vessieres, A.; Amatore, C. Quantitative analyses of ROS and RNS production in breast cancer cell lines incubated with ferrocifens. ChemMedChem 2014, 9 (6), 1286-1293. 
20. Hamels, D.; Dansette, P. M.; Hillard, E. A.; Top, S.; Vessieres, A.; Herson, P.; Jaouen, G.; Mansuy, D. Ferrocenyl quinone methides as strong antiproliferative agents: formation by metabolic and chemical oxidation of ferrocenyl phenols. Angew. Chem. Int. Ed. 2009, 48 (48), 9124-9126.

21. Messina, P.; Labbe, E.; Buriez, O.; Hillard, E. A.; Vessieres, A.; Hamels, D.; Top, S.; Jaouen, G.; Frapart, Y. M.; Mansuy, D.; Amatore, C. Deciphering the activation sequence of ferrociphenol anticancer drug candidates. Chem. Eur. J. 2012, 18 (21), 6581-6587.

22. Gormen, M.; Pigeon, P.; Top, S.; Hillard, E. A.; Huche, M.; Hartinger, C. G.; de Montigny, F.; Plamont, M. A.; Vessieres, A.; Jaouen, G. Synthesis, cytotoxicity, and COMPARE analysis of ferrocene and [3]ferrocenophane tetrasubstituted olefin derivatives against human cancer cells. ChemMedChem 2010, 5 (12), 2039-2050.

23. Citta, A.; Folda, A.; Bindoli, A.; Pigeon, P.; Top, S.; Vessieres, A.; Salmain, M.; Jaouen, G.; Rigobello, M. P. Evidence for targeting thioredoxin reductases with ferrocenyl quinone methides. A possible molecular basis for the antiproliferative effect of hydroxyferrocifens on cacer cells. J. Med. Chem. 2014, 57 (21), 8849-8859.

24. Bruyere, C.; Mathieu, V.; Vessières, A.; Pigeon, P.; Top, S.; Jaouen, G.; Kiss, R. Ferrocifen derivatives that induce senescence in cancer cells selected examples. J. Inorg. Biochem. 2014, 141, 144-151.

25. Vessieres, A.; Corbet, C.; Heldt, J. M.; Lories, N.; Jouy, N.; Laios, I.; Leclercq, G.; Jaouen, G.; Toillon, R. A. A ferrocenyl derivative of hydroxytamoxifen elicits an estrogen receptor-independent mechanism of action in breast cancer cell lines. J. Inorg. Biochem. 2010, $104(5), 503-511$. 
26. Wang, Y.; Pigeon, P.; Top, S.; McGlinchey, M. J.; Jaouen, G. Organometallic antitumor compounds: ferrocifens as precursors to quinone methides. Angew. Chem. Ed. Int. 2015, 54 (35), $10230-10233$.

27. Richard, M.-A.; Hamels, D.; Pigeon, P.; Top, S.; Dansette, P. M.; Lee, H. Z. S.; Vessières, A.; Mansuy, D.; Jaouen, G. Oxidative metabolism of ferrocene analogues of Tamoxifen: characterization and antiproliferative activities of the metabolites. ChemMedChem 2015, 10 (6), 981-990.

28. Wang, Y.; Richard, M. A.; Top, S.; Dansette, P. M.; Pigeon, P.; Vessieres, A.; Mansuy, D.; Jaouen, G. Ferrocenyl quinone methide-thiol adducts as new antiproliferative agents: synthesis, metabolic formation from ferrociphenols, and oxidative transformation Angew. Chem. Ed. Int. 2016, 55 (35), 10431-10434.

29. Wieczorek, A.; Błauż, A.; Zakrzewski, J.; Rychlik, B.; Plażuk, D. Ferrocenyl 2,5piperazinediones as tubulin-binding organometallic $\mathrm{ABCB} 1$ and $\mathrm{ABCG} 2$ inhibitors active against MDR cells. ACS Med. Chem. Lett. 2016, 7 (6), 612-617.

30. James, P.; Neudörfl, J.; Eissmann, M.; Jesse, P.; Prokop, A.; Schmalz, H.-G. Enantioselective synthesis of ferrocenyl nucleoside analogues with apoptosis-inducing activity. Org. Lett. 2006, 8 (13), 2763-2766.

31. Kowalski, K.; Skiba, J.; Oehninger, L.; Ott, I.; Solecka, J.; Rajnisz, A.; Therrien, B. Metallocene-modified uracils: synthesis, structure, and biological activity. Organometallics 2013, $32(20), 5766-5773$.

32. Nguyen, H. V.; Sallustrau, A.; Balzarini, J.; Bedford, M. R.; Eden, J. C.; Georgousi, N.; Hodges, N. J.; Kedge, J.; Mehellou, Y.; Tselepis, C.; Tucker, J. H. R. Organometallic nucleoside analogues with ferrocenyl linker groups: synthesis and cancer cell line studies. J. Med. Chem. 2014, 57 (13), 5817-5822. 
33. Parveen, H.; Hayat, F.; Salahuddin, A.; Azam, A. Synthesis, characterization and biological evaluation of novel 6-ferrocenyl-4-aryl-2-substituted pyrimidine derivatives. Eur. $J$. Med. Chem. 2010, 45 (8), 3497-3503.

34. Shen, S.-L.; Shao, J.-H.; Luo, J.-Z.; Liu, J.-T.; Miao, J.-Y.; Zhao, B.-X. Novel chiral ferrocenylpyrazolo[1,5-a][1,4]diazepin-4-one derivatives - synthesis, characterization and inhibition against lung cancer cells. Eur. J. Med. Chem. 2013, 63, 256-268.

35. Rodionov, A. N.; Zherebker, K. Y.; Snegur, L. V.; Korlyukov, A. A.; Arhipov, D. E.; Peregudov, A. S.; Ilyin, M. M.; Ilyin, M. M., Jr.; Nikitin, O. M.; Morozova, N. B.; Simenel, A. A. Synthesis, structure and enantiomeric resolution of ferrocenylalkyl mercaptoazoles. Antitumor activity in vivo. J. Organomet. Chem. 2015, 783, 83-91.

36. Deepthi, S. B.; Trivedi, R.; Giribabu, L.; Sridhar, B.; Sujitha, P.; Kumar, C. G. Ferrocenyl pseudo-dipeptides derived from 1,2-O-isopropylidene-alpha-D-xylofuranose: synthesis, electrochemistry and cytotoxicity evaluation. J. Organomet. Chem. 2014, 774, 26-34.

37. Arezki, A.; Chabot, G. G.; Quentin, L.; Scherman, D.; Jaouen, G.; Brule, E. Synthesis and biological evaluation of novel ferrocenyl curcuminoid derivatives. MedChemComm 2011, 2 (3), 190-195.

38. Tiwari, K. N.; Monserrat, J.-P.; Hequet, A.; Ganem-Elbaz, C.; Cresteil, T.; Jaouen, G.; Vessieres, A.; Hillard, E. A.; Jolivalt, C. In vitro inhibitory properties of ferrocene-substituted chalcones and aurones on bacterial and human cell cultures. Dalton Trans. 2012, 41 (21), 64516457.

39. Monserrat, J. P.; Tiwari, K. N.; Quentin, L.; Pigeon, P.; Jaouen, G.; Vessieres, A.; Chabot, G. G.; Hillard, E. A. Ferrocenyl flavonoid-induced morphological modifications of endothelial cells and cytotoxicity against B16 murine melanoma cells. J. Organomet. Chem. 2013, 734, 7885. 
40. Pulukkody, R.; Chupik, R. B.; Montalvo, S. K.; Khan, S.; Bhuvanesh, N.; Lim, S.-M.; Darensbourg, M. Y. Toward biocompatible dinitrosyl iron complexes: sugar-appended thiolates. Chem. Commun. 2017, 53 (6), 1180-1183.

41. Gómez, J.; Klahn, A. H.; Fuentealba, M.; Sierra, D.; Olea-Azar, C.; Maya, J. D.; Medina, M. E. Ferrocenyl and cyrhetrenyl azines containing a 5-nitroheterocyclic moiety: synthesis, structural characterization, electrochemistry and evaluation as anti-Trypanosoma cruzi agents. $J$. Organomet. Chem. 2017, 839, 108-115.

42. Hearn, J. M.; Romero-Canelon, I.; Munro, A. F.; Fu, Y.; Pizarro, A. M.; Garnett, M. J.; McDermott, U.; Carragher, N. O.; Sadler, P. J. Potent organo-osmium compound shifts metabolism in epithelial ovarian cancer cells. Proc. Natl. Acad. Sci. U. S. A. 2015, 112 (29), E3800-E3805.

43. Paunescu, E.; McArthur, S.; Soudani, M.; Scopelliti, R.; Dyson, P. J. Nonsteroidal antiinflammatory-organometallic anticancer compounds. Inorg. Chem. 2016, 55 (4), 1788-1808.

44. Najlaoui, F.; Pigeon, P.; Abdelkafi, Z.; Leclerc, S.; Durand, P.; El Ayeb, M.; Marrakchi, N.; Rhouma, A.; Jaouen, G.; Gibaud, S. Phthalimido-ferrocidiphenol cyclodextrin complexes: characterization and anticancer activity. Int. J. Pharm. 2015, 491 (1-2), 323-334.

45. Lu, J.; Palmer, B. D.; Kestell, P.; Browettm, P.; Baguley, B. C.; Muller, G.; Ching, L. M. Thalidomide metabolites in mice and patients with multiple myeloma. Clin. Cancer Res. 2003, 9 (5), 1680-1688

46. Plażuk, D.; Vessières, A.; Hillard, E. A.; Buriez, O.; Labbé, E.; Pigeon, P.; Plamont, M.A.; Amatore, C.; Zakrzewski, J.; Jaouen, G. A [3]Ferrocenophane polyphenol showing a remarkable antiproliferative activity on breast and prostate cancer cell lines. J. Med. Chem. 2009, $52(15), 4964-4967$. 
47. Fujii, S. Expanding the chemical space of hydrophobic pharmacophores: the role of hydrophobic substructures in the development of novel transcription modulators. MedChemComm 2016, 7 (6), 1082-1092.

48. Wang, Y.; Pigeon, P.; McGlinchey, M. J.; Top, S.; Jaouen, G. Synthesis and antiproliferative evaluation of novel hydroxypropyl-ferrociphenol derivatives, resulting from the modification of hydroxyl groups. J. Organomet. Chem. 2017, 829, 108-115.

49. Gherbovet, O.; Alvarez, M. C. G.; Bignon, J.; Roussi, F. Original vinca derivatives: from P-glycoprotein substrates to P-glycoprotein inhibitors. J. Med. Chem. 2016, 59 (23), 1077410780.

50. Sheldrick, G. M. A Short History of SHELX. Acta Cryst. A 2008, 64, 112-122.

51. Farrugia, L. J. WinGX suite for small-molecule single-crystal crystallography. J. Appl. Cryst. 1999, 32, 837-838.

52. Venot, C.; Maratrat, M.; Dureuil, C.; Conseiller, E.; Bracco L.; Debussche L. The requirement for the p53 proline-rich functional domain for mediation of apoptosis is correlated with specific PIG3 gene transactivation and with transcriptional repression. EMBO J. 1998, 17 (16), 4668-4679.

53. Romero-Canelon, I.; Salassa, L.; Sadler, P. J. The Contrasting activity of iodido versus chlorido ruthenium and osmium arene azo- and imino-pyridine anticancer complexes: control of cell selectivity, cross-resistance, p53 dependence, and apoptosis pathway. J. Med. Chem. 2013, $56(3), 1291-1300$. 


\section{Table of Contents Graphic}

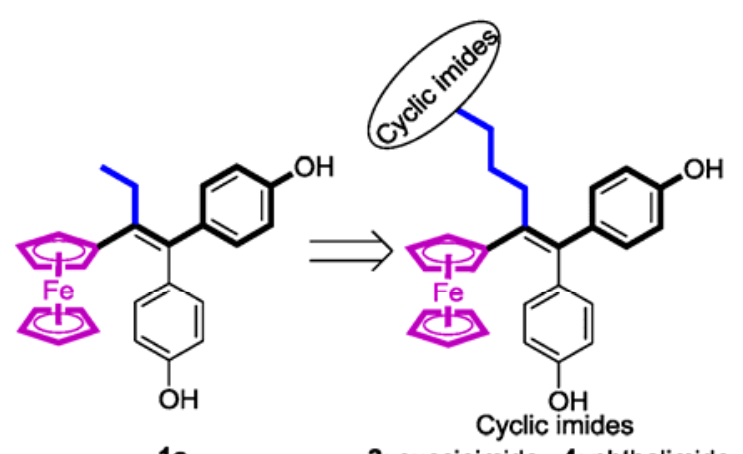
$\mathrm{A} 2780 \mathrm{IC}_{50}(\mu \mathrm{M})$ :
3.5
3: succinimide 4: phthalimide
A2780-Cis $\mathrm{IC}_{50}(\mu \mathrm{M}): 2.3$
0.035
0.16
0.049
0.074 